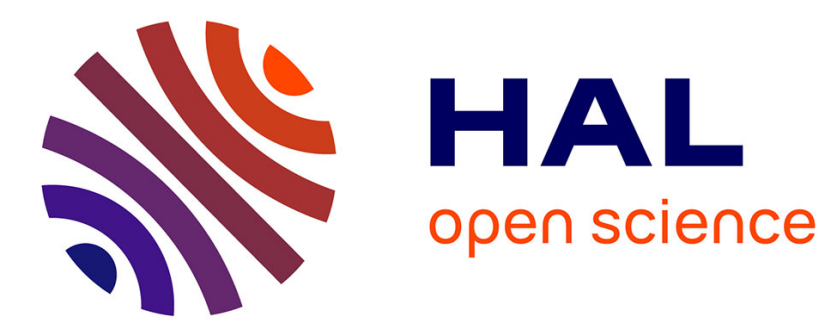

\title{
Uranium deposits of Franceville basin (Gabon): Role of organic matter and oil cracking on uranium mineralization
}

Andreï Lecomte, Raymond Michels, Michel Cathelineau, Christophe Morlot, Marc Brouand, Nicolas Flotte

\section{To cite this version:}

Andreï Lecomte, Raymond Michels, Michel Cathelineau, Christophe Morlot, Marc Brouand, et al.. Uranium deposits of Franceville basin (Gabon): Role of organic matter and oil cracking on uranium mineralization. Ore Geology Reviews, 2020, 123, pp.103579. 10.1016/j.oregeorev.2020.103579 . hal02861042

\section{HAL Id: hal-02861042 \\ https://hal.science/hal-02861042}

Submitted on 8 Jun 2020

HAL is a multi-disciplinary open access archive for the deposit and dissemination of scientific research documents, whether they are published or not. The documents may come from teaching and research institutions in France or abroad, or from public or private research centers.
L'archive ouverte pluridisciplinaire HAL, est destinée au dépôt et à la diffusion de documents scientifiques de niveau recherche, publiés ou non, émanant des établissements d'enseignement et de recherche français ou étrangers, des laboratoires publics ou privés. 


\section{Uranium deposits of Franceville basin (Gabon): Role of}

\section{organic matter and oil cracking on uranium mineralization}

Andreï Lecomte ${ }^{1, *}$, Raymond Michels ${ }^{1}$, Michel Cathelineau ${ }^{1}$, Christophe Morlot $^{1}$, Marc Brouand ${ }^{2}$, Nicolas Flotté ${ }^{2}$.

${ }^{1}$ GeoRessources, Université de Lorraine, CNRS, CREGU, Boulevard des Aiguillettes B.P. 239 F-54506 Vandœuvre-lès-Nancy, France

${ }^{2}$ ORANO, 125 Avenue de Paris F-92320 Châtillon, France

*Corresponding author: GeoRessources, Boulevard des Aiguillettes B.P. 239 F54506 Vandoeuvre lès Nancy, France

E-mail address: Andrei.Lecomte@univ-lorraine.fr 
Graphical abstract

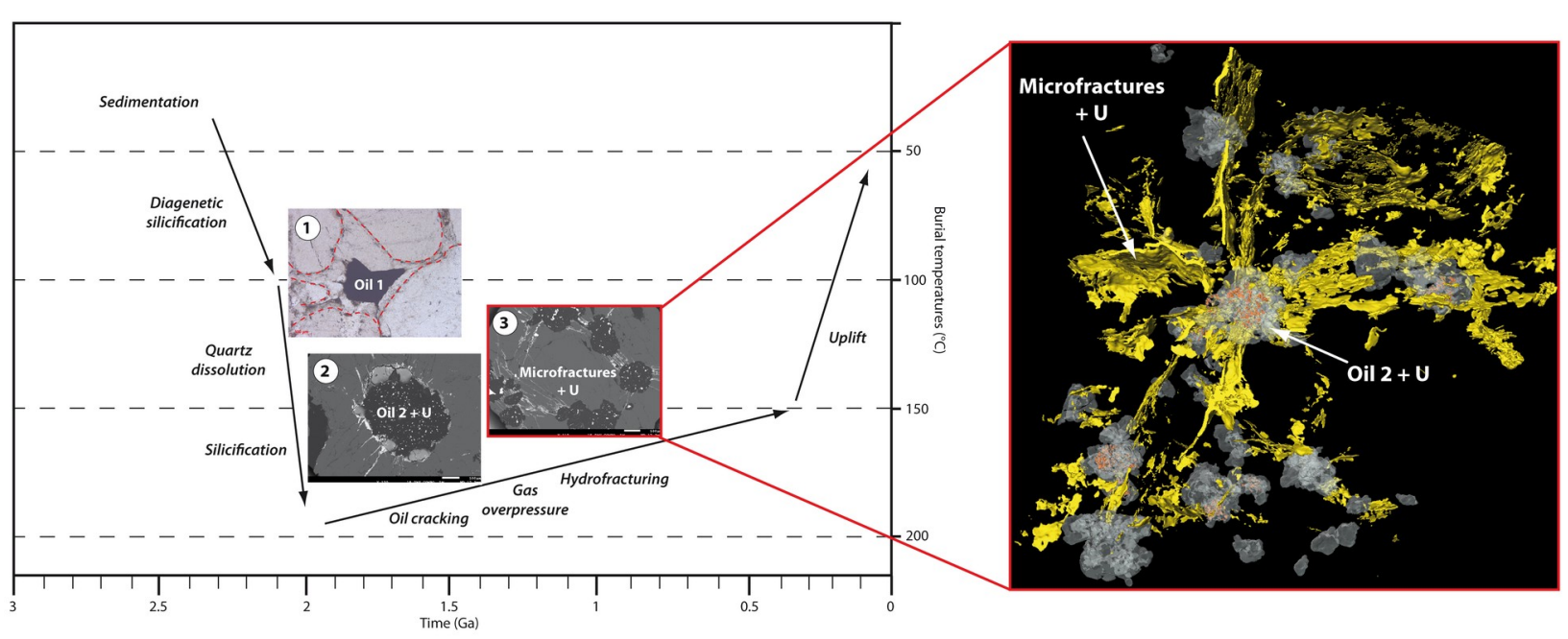




\section{Abstract}

The lower Proterozoic uranium deposits in the Franceville basin (Gabon) are mainly known to have hosted natural nuclear reactors. However, this basin also witnessed a former petroleum system which shows major occurrences of uranium ores associated with organic matter. The uranium mineralization is the result of several episodes of oil generation and migration, fluid mixing and hydrofracturing. During burial, at around $2.0 \mathrm{Ga}$, black shales were heated and expelled hydrocarbons which migrated in underlying sandstones. The first episode of oil migration was synchronous with a silicification event produced by a hot low salinity fluid, as shown by fluid inclusions trapped in quartz overgrowths. The second episode was contemporaneous with quartz dissolution and is characterized by the mixing of hydrocarbons and oxidizing U-bearing brine which resulted in the precipitation of $\mathrm{UO}_{2}$ inclusions in oil. Then, oil-to-gas conversion generated overpressured gas trapped in pores with uraniferous bitumen nodules. Changes in the stress regime probably favored radial hydrofracturing around bitumen nodules and subsequently the development of a pervasive micro-fracture network. There, $\mathrm{UO}_{2}$ precipitated together with $\mathrm{Cu}-\mathrm{Fe}$ sulfides through thermochemical sulfate reduction favored by the presence of hydrocarbons and methane.

Keywords: Uranium; Organic matter; Franceville basin; Hydraulic fracturing; Gas overpressure; X-ray tomography 


\section{Introduction}

In the Paleoproterozoic Franceville Series (Gabon) since the 1960s several high-grade uranium deposits have been discovered around the Oklo-Okélobondo, Bangombé and Mikouloungou areas. Since the discovery of natural nuclear reactions zones at Oklo in 1972, numerous studies have been carried out, in particular considering Oklo deposit as a natural analogue for nuclear waste repository. On the contrary, other deposits were less studied from the point of view of ore genesis. In the Franceville basin, uranium deposits are mainly located at the top of a basal arenaceous formation, below thick black shale series. Previous studies (e.g. Cortial, 1985; Gauthier-Lafaye, 1986; Gauthier-Lafaye \& Weber, 1989; Cortial et al., 1990; Mathieu, 1999; Mossmann, 2001; Mossmann et al., 2005) suggested a close link between uranium deposit occurrences and organic matter accumulation, thermal maturation and oil generation/migration. The purpose of this paper is to focus on genetic relationships between organic matter maturation, oil migration, uranium and sulfides precipitation without nuclear reaction overprints. To this end, we studied samples from Okélobondo, Bangombé and Mikouloungou areas, far enough from reactors to preclude any disturbance on petrographic and geochemical features. We propose an updated paragenetic sequence of hydrocarbon emplacement and mineralization and in particular a new insight into hydrofracturing in mineralized sandstones. 


\section{Geological setting}

The Francevillian basin is one of the seven Precambrian basins of the Congo craton. Francevillian sediments are generally discordant on the archean crystalline basement and cover around $35000 \mathrm{~km}^{2}$ over most central and eastern Gabon. The Francevillian basin is made up of several intracratonic elementary basins, namely Okondja basin, Booué basin, Lastourville basin and Franceville basin (Fig. 1), the latter hosting all Gabonese uranium deposits (Fig. 2). A comprehensive review of the opening of Francevillian intracratonic basins can be found in Weber et al. (2016). Weber (1968) divided sedimentary series into five formations named FA to FE from bottom to top (Fig. 3). FA formation (ca. 100 to 1000 meters from the edges to the center of the basin) is composed of fluviatile coarse sandstones and conglomerates overlain by tidal sandstones. This transition from fluviodeltaic to marine sedimentation is observed throughout the basin. Heavy minerals (zircons, monazite and thorite) are concentrated in coarse sandstones and conglomerates in the lower part of the formation. 400-1000 meters thick FB formation is mainly composed of black shales (ampelites), whose deposition may be related to the worldwide massive black shales event around 2 Ga. Ampelites are interstratified with sandstones (in particular bitumen-rich black sandstones) and dolomites. Near the top of the FB formation, Mn-carbonates become dominant over Fe-carbonates and constitute the protore of the manganese deposits. The transition from Fe-carbonates to Mn-carbonates is a first redox change to a more oxidizing system (Gauthier-Lafaye and Weber, 2003) and 
witness of the oxygen enrichment of the atmosphere (Holland, 2002; El Albani et al., 2010, 2014). FC formation (ca. 10-40 meters) is mainly made up with thickbanded cherts and jaspers, associated with dolomite and black shale beds. Overlying FD and FE formations are dominated by volcano-sedimentary series. FD formation is composed of black shales and welded tuffs at the top of the formation. FE formation consists of pyroclastic sandstones interlayered with shales.

The Franceville basin encloses five uranium deposits, from North to South: Boyindzi, Mounana, Oklo-Okélobondo, Bangombé and Mikouloungou. Uranium deposits are located at the top of the FA formation in the vicinity of FA-FB limit. Mineralized areas are therefore related to stratigraphic or tectonic contact between FA sandstones and FB black shales.

In the Franceville basin, organic matter is located in the petroleum sourcerocks of the FB formation (ampelites), along migration pathways and in reservoir facies such as FA sandstones or dolomites (e.g. Cortial, 1985; Cortial et al., 1990; Gauthier-Lafaye and Weber, 1989; Mossman et al., 2005). FB ampelites contain high levels of organic matter with Total Organic Carbon ranging from a few percents to $15 \%$ in the richest layers. Detailed compositions can be found for instance in Cortial (1985), Gauthier-Lafaye (1986), Ossa-Ossa (2010), or Ngombi-Pemba et al. (2014). In mineralized facies association between organic matter and uranium has long been described, based on $\mathrm{UO}_{2}$ inclusions within bitumen nodules (Cortial, 1985; Cortial et al., 1990; Gauthier-Lafaye and Weber, 
1989; Parnell, 1996) and in micro-fractures related to hydrofracturing (GauthierLafaye and Weber, 1989). The deposit of $\mathrm{U}$ mineralization is produced by interaction between migrated hydrocarbons and U-bearing brines in a continental rifting geological context (e.g. Gauthier-Lafaye and Weber, 1989; GauthierLafaye, 2006; Boiron et al., 2010). During burial, ampelites reached oil window and hydrocarbons were expelled in FA sandstones. Oxidizing brines led to monazite dissolution and leaching as well as liberation of U (Mathieu et al., 2001). Previous studies (Gauthier-Lafaye and Weber, 1989; Gauthier-Lafaye, 2006) suggested a major tectonic event responsible for major fault reactivation, fluid migration and $\mathrm{U}$ mineralization. Hydrocarbons were then trapped in structural high levels at the top of FA reservoirs and mixed with U-bearing fluids circulating in FA sandstones. These petroleum traps, located at footwall anticlines, are controlled by longitudinal normal faults and permeability barriers at FA-FB transition (Ndongo et al., 2016). Fluid circulation and mixing was favored by intense hydrofracturing of previously highly silicified sandstones, related to the development of overpressures in undercompacted zones (Gauthier-Lafaye and Weber, 1989).

\section{Sampling and analytical procedure}

Sampling procedure aimed at selecting representative black shales, sandstones and silts across the FA-FB limit to focus on relationships between organic matter and uranium mineralization. Samples were taken on several drill

cores from Mikouloungou, Bangombé and Mingara. Historical samples from 
Oklo-Okélobondo and Leyou locations were also studied (samples kept by ORANO, from COGEMA's drilling campaigns in the 1980s and 1990s). Studies were conducted on thin sections and polished sections, the latter consisting of small rock samples included with Araldite in an aluminum ring of $25 \mathrm{~mm}$ diameter.

Petrographical studies were done using optical microscope in reflected light and a FEG SEM JEOL 7600F (hot cathode) with an Oxford Instruments SDDtype EDS spectrometer. Electron microprobe (EPMA) analyses were performed using a CAMECA SX100, with an acceleration voltage of $20 \mathrm{kV}$ and beam current of $20 \mathrm{nA}$.

Multi-element concentrations in organic matter and Rare Earth Elements concentrations in uraninite were measured using a LA-ICP-MS system composed of a GeoLas excimer laser (ArF, 193 nm, Microlas, Göttingen, Germany) associated with an Agilent 7500c quadrupole ICP-MS. Quantification of the results was achieved using two standards CONOSTAN 500 and NIST SRM 610 (Pearce et al., 1997), and subroutine data processing (Leisen, 2011).

3D relationships between organic matter, uraninite inclusions and fractures in two mineralized sandstones (Okélobondo and Bangombé) were investigated by Xray microfocus computed tomography (XMCT) using a Phoenix-GE Nanotom S 180kV/15W scanner. Data acquisition for Okélobondo sample was performed at an acceleration voltage of $115 \mathrm{kV}$ and a beam current of $125 \mu \mathrm{A}$. The distances between the X-ray source from the detector and between the X-ray source and the sample were $30 \mathrm{~mm}$ and $500 \mathrm{~mm}$, respectively. The images acquired after a full 
$360^{\circ}$ rotation had a voxel size of $3 \mu \mathrm{m}^{3}$. Data acquisition for Bangombé sample was performed at an acceleration voltage of $100 \mathrm{kV}$ and a beam current of $80 \mu \mathrm{A}$. The distances between the X-ray source from the detector and between the X-ray source and the sample were $50 \mathrm{~mm}$ and $313 \mathrm{~mm}$, respectively. The images acquired after a full $360^{\circ}$ rotation had a voxel size of $8 \mu \mathrm{m}^{3}$. Three-dimensional reconstruction of the sample was performed using VGStudio Max 2.2 software and images were post-processed with FEI Avizo Fire 9.2 software.

\section{Results}

\subsection{Organic petrography}

In FA sandstones, organic matter occurs in two different forms (Fig. 4): massive spheroids/nodules and angular fragments of bitumen with (sub-)conchoidal fractures. Although both bitumen types may coexist in rare samples (Fig. 4h), their relationships with the host rock and in particular detrital grains are rather distinct. Indeed, angular shaped bitumens are located within the sandstone primary porosity, trapped in quartz overgrowths or in residual porosity between overgrowths (Fig. 4a and b). In FA sandstones, angular bitumens are synchronous to or later than silicification. On the contrary, in FB sandstones within black shales, bitumens fill out primary porosity as quartz overgrowths are rare. Bitumens are evidences of an early oil migration which limited sandstone silicification. These bitumen fillings do not contain any uraninite inclusions. Conversely, bitumen nodules, whether barren or mineralized, are located in the secondary porosity, in contact with dissolution surfaces (Fig. 4c). Some heavy 
minerals such as zircons are found as dissolution remnants within organic matter (Fig. 4d). Dissolution features and bitumen nodules are generally lined up along weakness areas such as interfaces between detrital grains and overgrowths.

\subsection{Trace elements distribution in bitumen}

Bitumens in FA sandstones, whether mineralized or not, show important heterogeneities of their reflectance (Fig. 4e and f). In particular, many bitumens display a progressive reflectance drop from core to rim. X-ray mapping suggest that lower reflectance halos (Fig. 4f) contain higher concentrations of $\mathrm{U}, \mathrm{Cu}, \mathrm{Fe}$ and S (Fig. 5) which are not expressed as visible mineral phases under SEM. Trace element concentration in nodules and angular bitumens measured by LAICP-MS are presented in Table 1. Only $\mathrm{S}, \mathrm{Ti}, \mathrm{V}, \mathrm{Mn}, \mathrm{Fe}, \mathrm{Ni}$ and $\mathrm{Cu}$ concentrations were high enough to be measured accurately. $\mathrm{U}$ was not present in our organic standard and was thus not determined. Angular bitumens have low metal concentrations: $\mathrm{Ti}, \mathrm{V}, \mathrm{Mn}, \mathrm{Fe}, \mathrm{Cu}$ range between a few ppm (often below detection limit) and less than $100 \mathrm{ppm}$ (except for Fe which is up to $275 \mathrm{ppm}$ ). Bitumen nodules have higher metal concentration than angular bitumens. Ti, V, $\mathrm{Mn}$ and Fe range between a few ppm (up to $182 \mathrm{ppm} \mathrm{Fe}$ ) and several thousands of ppm. Lower reflectance halos contain higher metal concentration than pristine bitumen cores and angular bitumens in particular. $\mathrm{Ti}, \mathrm{V}, \mathrm{Mn}, \mathrm{Fe}, \mathrm{Cu}$ concentrations range between tens of ppm (mostly over a hundred ppm) and several tens of thousands ppm (Fig. 6). Difference between concentrations in bitumen and halos is particularly high for $\mathrm{Fe}$ and $\mathrm{Cu}$ (Fig. 6b). 


\subsection{Petrography of uranium mineralization}

In FA sandstones, uranium distribution is generally linked to the presence of bituminous nodules (Fig. 7). In these nodules, uranium occurs as i) nanometer to micrometer scale inclusions of $\mathrm{UO}_{2}$ homogeneously disseminated in the bitumen matrix (Fig. 7a). $\mathrm{UO}_{2}$ inclusions display an angular shape, sometimes close to the cubic shape of euhedral uraninite (Fig. 7b); and as ii) veinlets and fillings of large voids (up to a few millimeters; Fig. 7c and d). $\mathrm{UO}_{2}$ crystals are trapped with quartz within bitumen voids suggesting that uranium precipitation is sub-synchronous with a major stage of silicification and porosity reduction. It is important to notice that some $\mathrm{UO}_{2}$ veinlets are elongated and bended underlining bitumen deformation (Fig. 7c). As previously described, uraniferous bitumens and angular bitumen sometimes display alteration halos that are enriched in $\mathrm{U}$, together with $\mathrm{Cu}$ and $\mathrm{Fe}$ (Fig. $7 \mathrm{~b}$ and $\mathrm{g}$ ).

In addition to the uranium mineralization associated with bitumen, an important part of $\mathrm{UO}_{2}$ in mineralized sandstones is located in micro-fractures and secondary porosity devoid of organic matter (Fig. 7e to $\mathrm{h}$ and Fig. 8). $\mathrm{UO}_{2}$ is also observed in secondary porosity and cements clays (Fig. 8c to e). An additional occurrence of uranium mineralization is within mechanical weakness zones, in particular at the boundaries between detrital grains and overgrowths.

Uraninite is observed in fractures in association with sulfides (pyrite, chalcopyrite, sometimes altered to bornite or chalcocite, and rarely cobaltite or nickeliferous cobaltite) and sulfates as barite (Fig. 7 g and h, Fig. 8 f and g). Some $\mathrm{UO}_{2}$ occurs within sulfide growth zones. Fractures filled with calcite crosscut 
mineralized fractures. Rare calcite fillings are found in vugs with radial microfractures around.

\subsection{Uranium ore crystallochemistry}

The different types of uranium mineralization (disseminated inclusions in organic matter, voids in organic matter and fracture fillings, labeled as U1, U2 and U3, respectively) were analyzed with EPMA. Results are listed in table 2 in weight percents for major oxides. Atoms per formula units (APFU) of uranium minerals were calculated on the basis of two oxygens and one cation. In figure 9, U+Ca and $\mathrm{Ca}+\mathrm{P}$ concentrations are plotted against $\mathrm{Si}+\mathrm{P}$ and $\mathrm{U}+\mathrm{Si}$, respectively. $\mathrm{U} 1, \mathrm{U} 2$ and U3 are aligned between uraninite and coffinite end-members, most analyses close to uraninite, indicating a usual but very limited coffinitization of $\mathrm{UO}_{2}$. Low analytical totals in uranium minerals are probably related to micro-porosity or hydratation associated with coffinitization (Deditius et al., 2008). In U3, Ca+P concentrations are higher than in $\mathrm{U} 1$ and $\mathrm{U} 2$, and are above the 1:1 substitution line $\mathrm{U} \leftrightarrow \mathrm{Ca} / \mathrm{Si} \leftrightarrow \mathrm{P}$.

LA-ICP-MS REE analyses are reported in Table 3. REE spectra normalized to chondrite (chondrite REE concentrations after Boynton, 1984) are plotted in Fig. 10. U1 and U2 display a rather similar pattern, with a bell shape, centered on light rare earth elements (LREE) and more or less flattened depending on the localities. However, U2 patterns display a negative Eu anomaly which is not observed in U1 uraninites. U3 REE patterns are highly fractionated between LREE and HREE, in favor of LREE. Some samples also display a positive Eu or 
Gd anomaly. Besides, REE enrichment (measured by $\Sigma$ REE parameter in figure 11a) is highly variable from a few hundred ppm to several thousand ppm and depends on the sample origin. On the contrary, fractionation between LREE and HREE, measured by $(\Sigma \text { LREE/ } \Sigma \text { HREE })_{\mathrm{N}}$ is similar in U1 and U2 but higher in U3. In figure $11 b, \mathrm{Eu}$ anomaly $\mathrm{Eu} / \mathrm{Eu}^{*}$ is plotted against $\mathrm{Y} / \Sigma$ REE. U1 and U2 uraninites have a similar $\mathrm{Y} / \Sigma \mathrm{REE}$ ratio but $\mathrm{U} 2$ displays a negative Eu anomaly $\left(\mathrm{Eu} / \mathrm{Eu}^{*}<1\right)$, which is not observed in $\mathrm{U} 1\left(\mathrm{Eu} / \mathrm{Eu}^{*}=1\right)$. In $\mathrm{U} 3, \mathrm{Y} / \Sigma \mathrm{REE}$ ratio is low and most REE patterns display a highly positive Eu anomaly. This kind of spectra, highly fractionated between LREE and HREE, has already been measured in vein-type or roll-front deposits (Kazakhstan, Mercadier et al., 2011) and monazite spectrum as a possible source of rare earth elements.

\subsection{Uranium distribution study by X-ray tomography}

Spatial relationships between $\mathrm{U} 1, \mathrm{U} 2$ and $\mathrm{U} 3$ were obtained by X-ray computed tomography. Two samples from Okélobondo and Bangombé were scanned to build the 3D representation of bitumen nodule shapes and uraninite distribution.

In Okélobondo sample (Fig. 12a to d), $\mathrm{UO}_{2}$ occurs as uraninite inclusions in nodules as well as in the surrounding fracture network connecting bitumen nodules. Moreover, fracture density seems to increase with nodule size. The total volume of connected network was calculated and corresponds to $1.7 \%$ of the sample. This estimation may be slightly underestimated considering that some isolated objects were ignored because of small size or insufficient contrast, but the 
latter have no significant impact on the total volume. Uraninite inclusions in organic matter represent $0.27 \%$ (i.e. $0.98 \mathrm{wt} \% \mathrm{U}$ ) of the total sample volume, whereas mineralized fractures represent $0.31 \%$ (i.e. $1.13 \mathrm{wt} \% \mathrm{U}$ ).

In Bangombé sample (Fig. 12 e and f), bitumen nodules only contain minor primary $\mathrm{UO}_{2}$ inclusions but are rimmed by uraniferous halos. $\mathrm{UO}_{2}$ is also found in a dense fracture network. Grain boundaries are often too thin to be properly selected from the X-ray tomography image background and included in the connected volume, which could have been therefore slightly underestimated. Results show that the volume of uraniferous halos is variable but represents up to $90 \%$ of a nodule. The total volume of connected network was calculated and corresponds to $1.5 \%$ of the sample volume, close to the results obtained for Okélobondo sample. $\mathrm{UO}_{2}$ within bitumen represents only $0.005 \%$ of the sample volume, i.e. $0.02 \mathrm{wt} \% \mathrm{U}$. U mineralization associated with fractures represents $0.70 \%$ of the sample volume, i.e. $2.54 \mathrm{wt} \% \mathrm{U}$.

\subsection{Micro-fractures as revealed by uranium distribution}

The petrographical as well as X-ray tomography study of uranium minerals revealed a singular spatial distribution of micro-fractures (Fig. 4, 7 and 8). Their study in $3 \mathrm{D}$ allowed to clearly image their occurrence in space. The images indicate that around bitumen nodules contained in paleopores, fractures develop radially (Fig. 7b, e, f, Fig. 12e and f). When fracture propagation occurred to a sufficient close distance, micro-fractures form a connected network (Fig. 7f, Fig. $12 \mathrm{e}$ and f). Several features of fracture initiation and development are 
distinguished: (a) a development of fracture network proportional to proximity and size of bitumen nodules. When nodules are too small or too distant, fractures do not create a connected network. When nodules do not have critical size, the connected network does not reach pluricentimeter scale. (b) a preferential direction of major fracture networks, which may be related to the local stress field (Fig. 8a). (c) a development of major networks proportional to silicification. In particular, network connection is favored in completely silicified sandstones (Fig. 8a and b). (d) In partly silicified sandstones, where residual porosity is filled with clays (mostly Fe-chlorites with minor kaolinite and illite), fracturing allows connection with open pores and $\mathrm{UO}_{2}$ crystallization (Fig. 8c to e).

\subsection{Chlorite geothermometry}

Chlorites are frequently observed associated with illite in FA sandstones and were reported by several authors (e.g. Gauthier-Lafaye, 1986; Gauthier-Lafaye and Weber, 1989; Mathieu, 1999; Ossa-Ossa, 2010; Bankolé et al., 2015; OssaOssa et al., 2014). They are found in the porosity between corroded detrital grains or in fracture fillings and sometime host part of the mineralization (uranium in fractures, sulfides and sulfates). Interestingly, chlorite compositions can be used as a geothermometer (Cathelineau \& Nieva, 1985; Cathelineau, 1988; Vidal et al., 2005; Inoue et al., 2009; Bourdelle et al., 2013). Electron microprobe analyses were carried out on samples from Okélobondo, Bangombé and Mikouloungou. In a $\mathrm{Fe} /(\mathrm{Fe}+\mathrm{Mg})$ vs Si diagram, all analyses are mainly in the "daphnite" field (or around the daphnite-chamosite boundary) (Fig. 13). This dataset was used to 
calculate temperature using geothermometry procedure of Bourdelle et al. (2013) and the $\mathrm{Si}$ vs $\mathrm{R}^{2+}$ diagram (Bourdelle and Cathelineau, 2015; Fig. 14). For Mikouloungou and Bangombé samples, mean calculated temperatures are $195 \pm 41^{\circ} \mathrm{C}$ and $205 \pm 21^{\circ} \mathrm{C}$, respectively (Table 4). For Okélobondo samples, mean temperatures are much higher $\left(289 \pm 46^{\circ} \mathrm{C}\right)$, which may be related to the heat influence of nearby natural nuclear reactors.

\section{Discussion}

\subsection{Hydrocarbon emplacement stages $\mathrm{HC1}$ and $\mathrm{HC} 2$}

As previously described, bitumen is present as massive spheroids/nodules and angular bitumen. In FA sandstones, angular bitumen is synchronous to or later than main silicification stage. Within the FB ampelites formation, unconsolidated sand layers contain bitumen which seems to have prevented silicification. Such features may suggest an early hydrocarbon migration episode called $\mathrm{HC} 1$ along unsilicified sandstone drains within FB formation to partially silicified primary porosity in sandstones from FA formation (Fig. 4a and b, Fig. 15).

Bitumen nodules, on the contrary, whether barren or mineralized, are found in contact with dissolution surfaces (along grain contact for instance) and filling secondary porosity (Fig. 4c, Fig. 7b, e and f, Fig. 15). Therefore, quartz dissolution pre-dates or is contemporaneous with bitumen nodule emplacement (called HC2, Fig. 15). 


\subsection{Uranium emplacement $U 1$ and $U 2$}

Accordingly to petrographic observations, oil migration occurred at least twice ( $\mathrm{HC} 1$ and $\mathrm{HC} 2$, Fig. 15) from a common source rock (i.e. FB ampelites) through FA sandstones. Yet, $\mathrm{HC} 1$ does not contain uranium inclusions. On the contrary, bitumen nodules (HC2) contain disseminated (sub-)euhedral $\mathrm{UO}_{2}$ crystals. This observation suggests that a first episode of uranium precipitation (U1) is linked to a mixing of petroleum ( $\mathrm{HC} 2$ ) with uranium-bearing fluids leading to reduction of uranyl ions to uraninite, as already suggested by Cortial et al. (1990) or Parnell (1996). This model is also supported by fluid inclusion analysis (Mathieu et al., 2000; Dutkiewicz et al., 2007) indicating mixing between brines and liquid hydrocarbons.

Uranium is also present as $\mathrm{UO}_{2}$ veinlets within bitumen nodules ( $\left.\mathrm{HC} 2\right)$ which are sometimes elongated and bended following bitumen shape and deformation. These veins inside the nodules probably appear in bitumen that was still ductile and are probably due to deformation and retraction effects during solidification of the bitumen. Thus, we may observe $\mathrm{UO}_{2}$ crystallization during evolution of oil to bitumen, from small $\mathrm{UO}_{2}$ disseminated inclusions during oilwater mixing to veinlets when nodules become more and more viscous. While some authors suggested that bitumen evolution was related to radiation-induced polymerization (Eakin and Gize, 1992; Parnell, 1996), we may also consider thermally driven transition from oil to bitumen, which triggers volume decrease by bitumen shrinkage and vug formation (Rasmussen and Krapez, 2000).

Vugs within bitumen are then filled with uranium (U2) and cemented by 
quartz. U1 and U2 display highly similar chemical composition and REE patterns, close to uraninites from unconformity-related uranium deposits (Mercadier et al., 2011; Alexandre et al., 2015), although the latter display REE patterns centered on $\mathrm{Tb}$ rather than lighter REE such as Pr to Sm. In unconformity-related deposits, $\mathrm{UO}_{2}$ crystallization is related to the circulation of $120-230^{\circ} \mathrm{C}$ basinal brines for the leaching of U-bearing minerals (possibly monazites) and subsequent $\mathrm{U}$ transportation (Mercadier et al., 2011) and the presence of several potential reducing agents for $\mathrm{U}$ precipitation. In the Franceville basin, oxidizing brines led to monazite dissolution and leaching of LREE, $U$ and P. Transport of $U$ and REE in brines was probably favored by chloride complexes (Mathieu et al., 2001). The large drop in LREE content may be explained by the cogenetic crystallization of LREE-rich aluminum phosphate-sulfate minerals (APS), preventing LREE integration in $\mathrm{UO}_{2}$ structure and leading to a bell-shaped pattern (Gaboreau et al., 2007). In FA sandstones, APS are described in the secondary porosity, associated with chlorite and illite (Ossa-Ossa, 2010; Ossa-Ossa et al., 2014). Besides, REE patterns in $\mathrm{U} 1$ and $\mathrm{U} 2$ are also similar to those found in uraninites from breccia pipe deposits (Lach, 2012), where $\mathrm{U}$ and $\mathrm{Cu}$ are transported by oxidized brines at temperatures ranging from 80 to $173^{\circ} \mathrm{C}$ (Wenrich, 1985). The strong Eu anomaly in $\mathrm{U} 2$ could be explained by a change in the redox conditions during the $\mathrm{U}$ crystallization succession from U1 to U2.

Chlorite and illite are also found in secondary porosity between corroded quartz grains and overgrowths. Temperatures recorded by chlorites suggest crystallization between 154 and $257^{\circ} \mathrm{C}$ (mean $203 \pm 26^{\circ} \mathrm{C}$ ). These temperatures are 
slightly lower than those calculated by Ossa-Ossa et al. (2014) with the procedure from Vidal et al. (2005), a geothermometer not fully adapted to low P-T conditions, but consistent with previous temperature estimates of $130-200^{\circ} \mathrm{C}$ for the mineralization based on fluid inclusions (Gauthier-Lafaye \& Weber, 1989; Mathieu et al., 2000; Dutkiewicz et al., 2007). Since chlorites crystallize after U2 deposition, the values measured would then set the maximum temperatures for mineralization episodes U1 and U2.

\subsection{Uranium emplacement $U 3$}

A third stage of uranium deposition (U3) is characterized by $\mathrm{UO}_{2}$ filling microfractures (Fig. 5, Fig. 7e to h, Fig. 8 a, e, f, Fig. 12). These fractures develop radially around bitumen nodules and often form a connected network. U3 mineralization displays different REE patterns, rather close to those measured in monazite, but with a larger fractionation between LREE and HREE (Fig. 10). Highly-fractionated REE patterns were reported in various geological settings such as vein-type or roll-front deposits (Mercadier et al., 2011; Alexandre et al., 2015), which makes it difficult to conclude on their significance.

$\mathrm{UO}_{2}$ in fractures (U3) is commonly associated with iron/copper sulfides (pyrite, chalcopyrite, bornite, covellite) and barite. This observation suggests the role of

sulfur fugacity $f \mathrm{~S}_{2}$ and related processes, $\mathrm{H}_{2} \mathrm{~S}$ inputs or thermochemical sulfate reduction (TSR), in the formation of copper and iron sulfides contemporaneous with uranium mineralization. Chalcopyrite is earlier than pyrite, with barite representing the last crystallized phase in fractures. Uranium bearing bitumen 
nodules (HC2) and less commonly angular bitumen (HC1) present lower reflectance halos at their rims (Fig. 5a, Fig. 7b) which contain systematically the same metals also precipitated as sulfides (Fig.7 $\mathrm{g}$ and $\mathrm{h}$ ). It appears that elements involved in fracture fillings $(\mathrm{U}, \mathrm{Fe}, \mathrm{Cu}, \mathrm{S})$ correspond to those found in bitumen reflectance halos. Reflectance variations and halos in kerogen and bitumen at the micrometer scale is often the indication of radiolytic damage in the Franceville basin (Mossman and Nagy, 1996). Together with the increased concentrations in $\mathrm{V}, \mathrm{Ni}, \mathrm{Fe}$ and $\mathrm{Cu}$, this suggests interactions with mineralizing fluids.

We thus propose that uranium occurring in micro-fractures and bitumen rims alteration (halos) is contemporaneous with sulfate reduction leading to copper sulfides and chalcopyrite precipitation, followed by pyrite and then barite.

\subsection{Mineralization emplacement and scenario}

The paragenetic sequence indicates that the primary $U$ ore formation corresponds to the burial history of the sediments coinciding with the P-T pair favoring oil formation.

During burial diagenesis, the pressure-solution process lead to silica redistribution and local FA sandstones silicification. In the meantime, the progressive thermal maturation of organic matter in black shales results in the production of hydrocarbons, and their subsequent expulsion. The latter are then trapped in nearby reservoirs, such as the FA sandstones, in particular in residual porosity between overgrowth boundaries (leading to the "angular bitumen" as called in the petrographic section) as well as within quartz overgrowths. This stage 
is sub-synchronous with the circulation of a hot low salinity fluid trapped in quartz overgrowths and previously described as "Type 1 " (4 wt $\left.\% \mathrm{NaCl}, 180^{\circ} \mathrm{C}\right)$ in Gauthier-Lafaye \& Weber, 1989 and $\mathrm{Lw}\left(2.2-8.5 \mathrm{wt} \% \mathrm{NaCl}, 200 \pm 10^{\circ} \mathrm{C}\right)$ in Mathieu et al., 2000. This fluid is considered as a meteoric recharge that was heated up through its migration in the basement and flowed upward in FA sandstones along major N-S faults (Mathieu et al., 2000).

The second phase (Fig. 15) is marked by quartz dissolution. Important secondary porosity is created by dissolution of the previous overgrowths and detrital grains (Fig. 4c). This porosity is filled by clays (chlorite and illite), calcite and accompanied by a second stage of oil trapping leading to the bitumen nodules. Most bitumen nodules host disseminated uraniferous inclusions and $\mathrm{UO}_{2}$ veinlets form creep patterns (U1). The most massive nodules have cracks or voids (probably resulting from the retraction of bitumen as it polymerized) filled with $\mathrm{UO}_{2}$ patches (U2) cemented by $\mathrm{SiO}_{2}$. Bituminous nodules in FA sandstones are thus related to a second stage of oil trapping, synchronous or later than massive quartz dissolution and acted as a reducing agent for $\mathrm{U}$. The $\mathrm{U}$ ores result probably from the interaction between bitumen and basinal brines, a process eventually strengthened by the dilution of the brines by meteoric fluids (Mathieu et al., 2000). According to Mathieu (1999), these fluids, dominated by $\mathrm{Na}-\mathrm{Ca}-\mathrm{Cl}$ and rich in $\mathrm{Li}, \mathrm{SO}_{4}$ and $\mathrm{Br}$, are in equilibrium with sulfates (anhydrite, gypsum and accessory barite) which had been reported by Gauthier-Lafaye and Weber (1989, 2003) as cements in sandstones within upper FA formation. The discordant limit of sulfate-cemented sandstones over the bedding indicates dissolution- 
precipitation processes during diagenesis. These brines circulated through basal FA conglomerates and are responsible for REE, $\mathrm{P}$ and $\mathrm{U}$ leaching (Mathieu et al., 2001). This is in accordance with the findings of Gauthier-Lafaye (1986), Gauthier-Lafaye and Weber (1989, 2003), Mathieu et al. (2000), Gauthier-Lafaye (2006), Bankole et al. (2016) who suggest that oxygenated ground waters leached the FA formation long after deposition of the sediments.

A third stage of uranium deposition (U3) is related to the formation of micro-fracture networks with radial distribution around bitumen. Filled pores and their interconnection accordingly to pore size and inter-distances as to create a complex network is typical of the space distribution of U3 mineralization. Such microfracturing can be related to the stages of hydraulic fracturing in the Franceville basin already inferred by Gauthier-Lafaye and Weber (1989).

Such textures display similarities with those described by Marquez and Mountjoy (1996) in reservoir rocks from the Alberta basin, where subhorizontal and radial fractures extend from vugs and intercrystalline pores. While tectonic stresses may not be completely ruled out, in particular for the development of main oriented fractures, failure initiation occurs as radial micro-fractures around pores filled with hydrocarbons. The strict spatial relationships between bitumenfilled pores and microfracture development suggests that thermal cracking of oil produced gas overpressure and triggered fracturing.

Barker (1990) demonstrated that thermal cracking of oil generates great amounts of gas and a volume increase of up to 400 times. If an isolated reservoir is completely filled with oil, then cracking of as little as $1 \%$ of the crude oil is 
enough to obtain pressures higher than lithostatic. His model was however based on the conversion of oil to methane and a carbonaceous residue with a complete conversion at $150^{\circ} \mathrm{C}$. Yet, it appears that oil is much more stable than considered by the kinetic model used by Barker (1990), up to temperatures as high as $200^{\circ} \mathrm{C}$ (e.g. Schenk et al, 1997; Domine et al., 1998; Vandenbroucke e al., 1999; Waples, 2000). Tian et al. (2008) rather used a full suite of gaseous components to represent oil to gas conversion, which is dominated by C1-C5 gases (Schenk et al., 1997; Waples, 2000). Results show that oil is stable to about $160^{\circ} \mathrm{C}$ and complete conversion occurs at $210^{\circ} \mathrm{C}$, considering a heating rate of $2^{\circ} \mathrm{C} / \mathrm{m}$.y. Oil conversion into gas at temperatures between $160^{\circ} \mathrm{C}$ and $200^{\circ} \mathrm{C}$ is therefore a major drive for gas formation in the tight silicified FA sandstones reservoir.

Tian et al. (2008) calculated volume and pressure changes in an isolated reservoir with $100 \%$ and $50 \%$ oil saturation. In the first case, overpressure may initiate fracturing above $200^{\circ} \mathrm{C}$, corresponding to an oil destruction of $95 \%$. In the second case, considering the lower compressibility of water compared to gases and gas dissolution in water, the maximum temperature before fracturing is $195^{\circ} \mathrm{C}$, corresponding to an oil destruction of about $86 \%$.

Numerous studies have been conducted to model fracture propagation in rocks (Ghani et al., 2013 and references therein). In particular, in the case of a homogeneous medium within an isotropic domain, it appears that fracturing occurs radially around overpressure source points. Considering a vertical gravitational load applied on a homogeneous material, fracture geometry is defined by deviatoric stresses: horizontal extension initiates vertical mode I hydrofractures, 
whereas compressive state of stress leads to conjugate shear fractures (Ghani et al., 2013).

We thus propose that thermal cracking of oil at temperatures close to that of maximal burial $\left(200^{\circ} \mathrm{C}\right.$; Gauthier-Lafaye \& Weber, 1989; Mathieu et al, 2000; Dutkiewicz et al., 2007) induced gas overpressures which played a major role in the hydrofracturing process.

There is a direct relationship between the hydraulic fracturing mechanism and the location of uranium ore in the studied deposits. The newly formed permeability network caused by hydraulic fracturing allowed circulation of the uranium-bearing fluid and then ore formation.

Since hydraulic fracturing is related to hydrocarbon gases overpressure, it is also proposed that dissolved hydrocarbons (e.g. methane; Dargent et al., 2015) are the reducing agent for uranium. The precipitation of sulfides may be triggered by reduced sulfur provided by the reaction of hydrocarbons (gases as well as bitumen) with dissolved sulfate through $\mathrm{TSR}$ at temperatures above $150^{\circ} \mathrm{C}$ (Machel, 2001). The formation of dissolved sulfides through TSR reactions may also be considered as a potential reducing agent for uranium. In particular, hydrogen sulfide is a candidate for $\mathrm{U}(\mathrm{VI})$ reduction despite slow reaction kinetics at rather low temperature which may require previous adsorption on organic matter or minerals like clays (Granger and Warren, 1969; Spirakis, 1981, 1996).

Therefore, we should consider two main events responsible for uranium mineralization in the Franceville basin: (a) during burial at around $2.0 \mathrm{Ga}$, oil migrated from black shales to sandstones and mixed with uranium bearing brines 
to form $\mathrm{UO}_{2}$ inclusions within bitumen $(\mathrm{U} 1+\mathrm{U} 2)$; (b) during uplift, deviatoric stresses were modified and allowed gas overpressure release by hydrofracturing, starting with radial fractures. These micro-fractures could expand and connect to create a network in which $\mathrm{UO}_{2}$ (U3) and sulfides could precipitate with the presence of $\mathrm{CH}_{4}$ and $\mathrm{H}_{2} \mathrm{~S}$ in conditions compatible with TSR. Major differences between $\mathrm{U} 1+\mathrm{U} 2$ and $\mathrm{U} 3$ (i.e. REE patterns, volume differences calculated with tomography) support this consideration and preclude any significant remobilization of primary uranium mineralization during hydrofracturing.

\section{Conclusions}

Main conclusions are the followings:

- The lower Proterozoic uranium deposits in the Franceville basin (Gabon) display a clear association between uranium ore and bitumens, which represent migrated oil within a petroleum system. Thus, U-ores result from a multi-stage mixing process between uranium-bearing brines and liquid or gaseous hydrocarbons controlled by sandstone porosity and hydrofracturing.

- Uranium was first precipitated (U1) at around 2.0 Ga when U-bearing brine interacted with oil expelled from FB and trapped in the FA sandstone reservoir. While petroleum evolved into bitumen, generation U2 of uranium precipitated. Meanwhile quartz cementation reduced significantly the porosity and hydrocarbon cracking during maximum burial temperature led to gas overpressure. Fluid overpressure together 
with changes in the stress field favored hydrofracturing. Dissolved hydrocarbons then acted as reducing agent for sulfur through TSR, leading to $\mathrm{Cu}-\mathrm{Fe}$ sulfides as well as $\mathrm{U}$ precipitation (U3).

This study reveals:

- The important role of petroleum systems in the control of metal precipitation, and the development of peculiar conditions favoring fissure permeability increase, and reduction conditions necessary for sulfide and U oxide precipitation.

- The effect of the organic matter evolution through diagenesis and thermal maturation leading to oil and then gas which participated to chemical and mechanical evolution of the reservoirs.

\section{Acknowledgments}

The authors would like to thank all members of AREVA Gabon, for welcoming us in Franceville and for their technical assistance in the sampling process. We thank S. Mathieu and O. Rouer for SEM/EPMA results and C. Peiffert for LA-ICP-MS analyses. We also thank E. Gaucher and an anonymous reviewer for their useful comments and suggestions.

This work was supported by ORANO through CREGU research project. 


\section{References}

Alexandre, P., Kyser, K., Layton-Matthews, D., Joy, B., Uvarova, Y., 2015. Chemical Compositions of Natural Uraninite. The Canadian Mineralogist $53,595-622$.

Bankole, O.M., El Albani, A., Meunier, A., Gauthier-Lafaye, F., 2015. Textural and paleo-fluid flow control on diagenesis in the Paleoproterozoic Franceville Basin, South Eastern, Gabon. Precambrian Research 268, $115-134$.

Bankole, O.M., El Albani, A., Meunier, A., Rouxel, O.J., Gauthier-Lafaye, F., Bekker, A., 2016. Origin of red beds in the Paleoproterozoic Franceville Basin, Gabon, and implications for sandstone-hosted uranium mineralization. American Journal of Science 316, 839-872.

Barker, C., 1990. Calculated volume and pressure changes during the cracking of oil and gas in reservoirs. AAPG Bulletin 74, 1254-1261.

Boiron, M.C., Cathelineau, M., Richard, A., 2010. Fluid flows and metal deposition near basement/cover unconformity: lessons and analogies from $\mathrm{Pb}-\mathrm{Zn}-\mathrm{F}-\mathrm{Ba}$ systems for the understanding of Proterozoic U deposits. Geofluids 10, 270-292.

Bourdelle, F., Cathelineau, M., 2015. Low-temperature chlorite geothermometry: a graphical representation based on a $\mathrm{T}-\mathrm{R} 2+-\mathrm{Si}$ diagram. European Journal of Mineralogy 27, 617-626.

Bourdelle, F., Parra, T., Chopin, C., Beyssac, O., 2013. A new chlorite 
geothermometer for diagenetic to low-grade metamorphic conditions. Contributions to Mineralogy and Petrology 165, 723-735.

Boynton, W.V., 1984. Cosmochemistry of the rare earth elements: meteorite studies, in: Henderson, P. (Ed.), Rare Earth Element Geochemistry. Elsevier Sci. Publ. Co., Amsterdam, pp. 63-114.

Cathelineau, M., 1988. Cation site occupancy in chlorites and illites as a function of temperature. Clay Minerals 23, 471-485.

Cathelineau, M., Nieva, D., 1985. A chlorite solid solution geothermometer the Los Azufres (Mexico) geothermal system. Contributions to Mineralogy and Petrology 91, 235-244.

Cortial, F., 1985. Les bitumes du Francevillien (Protérozoïque inférieur du Gabon, $2000 \mathrm{Ma}$ ) et leurs kérogènes. Relations avec les minéralisations uranifères. PhD Thesis, Université Louis Pasteur, Strasbourg, 183 p.

Cortial, F., Gauthier-Lafaye, F., Lacrampe-Couloume, G., Oberlin, A., Weber, F., 1990. Characterization of organic matter associated with uranium deposits in the Francevillian formation of Gabon (lower proterozoic). Organic Geochemistry 15, 73-85.

Dargent, M., Truche, L., Dubessy, J., Bessaque, G., Marmier, H., 2015. Reduction kinetics of aqueous $\mathrm{U}(\mathrm{VI})$ in acidic chloride brines to uraninite by methane, hydrogen or C-graphite under hydrothermal conditions: Implications for the genesis of unconformity-related uranium ore deposits. Geochimica et Cosmochimica Acta 167, 11-26.

Deditius, A.P., Utsunomiya, S., Ewing, R.C., 2008. The chemical stability of 
coffinite, $\mathrm{USiO}_{4} \cdot \mathrm{nH}_{2} \mathrm{O} ; 0<\mathrm{n}<2$, associated with organic matter: A case study from Grants uranium region, New Mexico, USA. Chem. Geol. $251,33-49$.

Dominé, F., Dessort, D., Brévart, O., 1998. Towards a new method of geochemical kinetic modelling:implications for the stability of crude oils. Organic Geochemistry 28, 597-612.

Dutkiewicz, A., George, S.C., Mossman, D.J., Ridley, J., Volk, H., 2007. Oil and its biomarkers associated with the Palaeoproterozoic Oklo natural fission reactors, Gabon. Chemical Geology 244, 130-154.

Eakin, P.A., Gize, A.P., 1992. Reflected-light microscopy of uraniferous bitumens. Mineralogical magazine 56, 85-99.

El Albani, A., Bengtson, S., Canfield, D.E., Bekker, A., Macchiarelli, R., Mazurier, A., Hammarlund, E.U., Boulvais, P., Dupuy, J.-J., Fontaine, C., Fürsich, F.T., Gauthier-Lafaye, F., Janvier, P., Javaux, E., Ossa, F.O., Pierson-Wickmann, A.-C., Riboulleau, A., Sardini, P., Vachard, D., Whitehouse, M., Meunier, A., 2010. Large colonial organisms with coordinated growth in oxygenated environments $2.1 \mathrm{Gyr}$ ago. Nature 466, 100-104.

El Albani, A., Bengtson, S., Canfield, D.E., Riboulleau, A., Rollion Bard, C., Macchiarelli, R., Ngombi Pemba, L., Hammarlund, E., Meunier, A., Moubiya Mouele, I., Benzerara, K., Bernard, S., Boulvais, P., Chaussidon, M., Cesari, C., Fontaine, C., Chi-Fru, E., Garcia Ruiz, J.M., Gauthier-Lafaye, F., Mazurier, A., Pierson-Wickmann, A.C., Rouxel, O., 
Trentesaux, A., Vecoli, M., Versteegh, G.J.M., White, L., Whitehouse, M., Bekker, A., 2014. The 2.1 Ga Old Francevillian Biota: Biogenicity, Taphonomy and Biodiversity. PLOS ONE 9, e99438.

Feybesse, J.L., Johan, V., Triboulet, C., Guerrot, C., Mayaga-Mikolo, F., Bouchot, V., Eko N'dong, J., 1998. The West Central African belt: a model of $2.5-2.0 \mathrm{Ga}$ accretion and two-phase orogenic evolution. Precambrian Research 87, 161-216.

Gaboreau, S., Cuney, M., Quirt, D., Beaufort, D., Patrier, P., Mathieu, R., 2007. Significance of aluminum phosphate-sulfate minerals associated with $\mathrm{U}$ unconformity-type deposits: The Athabasca basin, Canada. American Mineralogist 92, 267-280.

Gauthier-Lafaye, F., 1986. Les gisements d'uranium du Gabon et les réacteurs d'Oklo. Modèle métallogénique de gîtes à fortes teneurs du Protérozoïque inférieur, Sciences Géologiques, bulletins et mémoires.

Gauthier-Lafaye, F., 2006. Time constraint for the occurrence of uranium deposits and natural nuclear fission reactors in the Paleoproterozoic Franceville Basin (Gabon). Memoir of the Geological Society of America 198, 157-167.

Gauthier-Lafaye, F., Weber, F., 1989. The Francevillian (Lower Proterozoic) uranium ore deposits of Gabon. Economic Geology 84, 2267-2285.

Gauthier-Lafaye, F., Weber, F., 2003. Natural nuclear fission reactors: Time constraints for occurrence, and their relation to uranium and manganese deposits and to the evolution of the atmosphere. Precambrian Research 
$120,81-100$.

Ghani, I., Koehn, D., Toussaint, R., Passchier, C.W., 2013. Dynamic Development of Hydrofracture. Pure and Applied Geophysics 170, $1685-1703$.

Granger, H.C., Warren, C.G., 1969. Unstable sulfur compounds and the origin of roll-type uranium deposits. Economic Geology 64, 160-171.

Holland, H.D., 2002. Volcanic gases, black smokers, and the great oxidation event. Geochimica et Cosmochimica Acta 66, 3811-3826.

Inoue, A., Meunier, A., Patrier-Mas, P., Rigault, C., Beaufort, D., Vieillard, P., 2009. Application for chemical geothermometry to low-temperature trioctahedral chlorites. Clays and Clay Minerals 57, 371-382.

Lach, P., 2012. Signature géochimique des éléments des terres rares dans les oxydes d'uranium et minéraux associés dans les gisements d'uranium : analyse par ablation laser couplée à l' ICP-MS et étude géochronologique. PhD Thesis, Université de Lorraine, 295 p.

Leisen, M., 2011. Analyse chimique des inclusions fluides par ablation-laser couplée à l'ICP-MS et applications géochimiques. PhD Thesis, NancyUniversité, 318 p.

Machel, H.G., 2001. Bacterial and thermochemical sulfate reduction in diagenetic settings - old and new insights. Sedimentary Geology 140, 143-175.

Marquez, X., Mountjoy, E., 1996. Microfractures due to overpressures caused by thermal cracking in well-sealed Upper Devonian Reservoirs, Deep Alberta Basin 80 . 
Mathieu, R., 1999. Reconstitution des paléocirculations fluides et des migrations élémentaires dans l'environnement des réacteurs nucléaires naturels d'Oklo (Gabon) et des argilites de Tournemire (France). PhD Thesis, Institut National Polytechnique de Lorraine, 350 p.

Mathieu, R., Cuney, M., Cathelineau, M., 2000. Geochemistry of palaeofluids circulation in the Franceville basin and around Oklo natural nuclear reaction zones (Gabon). Journal of Geochemical Exploration 69-70, 245-249.

Mathieu, R., Zetterström, L., Cuney, M., Gauthier-Lafaye, F., Hidaka, H., 2001. Alteration of monazite and zircon and lead migration as geochemical tracers of fluid paleocirculations around the Oklo-Okélobondo and Bangombé natural nuclear reaction zones (Franceville basin, Gabon). Chemical Geology 171, 147-171.

Mercadier, J., Cuney, M., Lach, P., Boiron, M.C., Bonhoure, J., Richard, A., Leisen, M., Kister, P., 2011. Origin of uranium deposits revealed by their rare earth element signature. Terra Nova 23, 264-269.

Mossman, D.J., 2001. Hydrocarbon habitat of the Paleoproterozoic Franceville Series, Republic of Gabon. Energy Sources 23, 45-53.

Mossman, D.J., Gauthier-Lafaye, F., Jackson, S.E., 2005. Black shales, organic matter, ore genesis and hydrocarbon generation in the Paleoproterozoic Franceville Series, Gabon. Precambrian Research 137, 253-272.

Mossman, D.J., Nagy, B., 1996. Solid bitumens: an assessment of their characteristics, genesis, and role in geological processes. Terra Nova 8, 
$114-128$.

Ndongo, A., Guiraud, M., Vennin, E., Mbina, M., Buoncristiani, J.-F., Thomazo, C., Flotté, N., 2016. Control of fluid-pressure on early deformation structures in the Paleoproterozoic extensional Franceville Basin (SE Gabon). Precambrian Research 277, 1-25.

Ngombi-Pemba L., El Albani A., Meunier A., Grauby O., Gauthier-Lafaye F., 2014. From detrital heritage to diagenetic transformations, the message of clay minerals contained within shales of the Palaeoproterozoic Francevillian basin (Gabon). Precambrian Research 255, 63-76.

Ossa Ossa, F., 2010. Etude multi-approches du bassin sédimentaire paléoprotérozoïque (2.1-2.4 Ga) de Franceville au Gabon: les environnements sédimentaires et l'impact des paléocirculations de fluides. PhD Thesis, Université de Poitiers, 191 p.

Ossa Ossa, F., Hofmann, A., Vidal, O., Kramers, J.D., Agangi, A., Belyanin, G.A., Mayaga-Mikolo, F., 2014. Hydrothermal clay mineral formation in the uraniferous Paleoproterozoic FA Formation, Francevillian basin, Gabon. Precambrian Research 246, 134-149.

Parnell, J., 1996. Petrographic relationships between mineral phases and bitumen in the Oklo Proterozoic natural fission reactors, Gabon. Mineralogical Magazine 60, 581-593.

Pearce, N.J.G., Perkins, W.T., Westgate, J.A., Gorton, M.P., Jackson, S.E., Neal, C.R., Chenery, S.P., 1997. A compilation of new and published major and trace element data for NIST SRM 610 and NIST SRM 612 glass 
reference materials. Geostandards Newsletter-the Journal of Geostandards and Geoanalysis 21, 115-144.

Préat, A., Bouton, P., Thiéblemont, D., Prian, J.-P., Ndounze, S.S., Delpomdor, F., 2011. Paleoproterozoic high $\delta 13 \mathrm{C}$ dolomites from the Lastoursville and Franceville basins (SE Gabon): Stratigraphic and synsedimentary subsidence implications. Precambrian Research 189, 212-228.

Rasmussen, B., Krapez, B., 2000. Evidence of hydrocarbon and metalliferous fluid migration in the Palaeoproterozoic Earaheedy Basin of Western Australia. Journal of the Geological Society 157.

Schenk, H.J., Di Primio, R., Horsfield, B., 1997. The conversion of oil into gas in petroleum reservoirs. Part 1: Comparative kinetic investigation of gas generation from crude oils of lacustrine, marine and fluviodeltaic origin by programmed-temperature closed-system pyrolysis. Organic Geochemistry 26, 467-481.

Spirakis, C.S., 1981. The Possible Role of Sulfate Reduction Kinetics in the Formation of Hydrothermal Uranium Deposit. Economic Geology 76, 2236-2239.

Spirakis, C.S., 1996. The roles of organic matter in the formation of uranium deposits in sedimentary rocks. Ore Geology Reviews 11, 53-69.

Thiéblemont, D., Castaing, C., Billa, M., Bouton, P., Préat, A., 2009. Notice explicative de la Carte géologique et des Ressources minérales de la République gabonaise à 1/1 000 000. Editions DGMG, Ministère des Mines, du Pétrole, des Hydrocarbures. Libreville, 384 p. 
Tian, H., Xiao, X., Wilkins, R.W.T., Tang, Y., 2008. New insights into the volume and pressure changes during the thermal cracking of oil to gas in reservoirs: Implications for the in-situ accumulation of gas cracked from oils. AAPG Bulletin 92, 181-200.

Vandenbroucke, M., Behar, F., Rudkiewicz, J.L., 1999. Kinetic modelling of petroleum formation and cracking: implications from the high pressure/high temperature Elgin Field (UK, North Sea). Organic Geochemistry 30, 1105-1125.

Vidal, O., Parra, T., Vieillard, P., 2005. Thermodynamic properties of the Tschermak solid solution in Fe-chlorite: Application to natural examples and possible role of oxidation. American Mineralogist 90, 347-358.

Waples, D.W., 2000. The kinetics of in-reservoir oil destruction and gas formation: constraints from experimental and empirical data, and from thermodynamics. Organic Geochemistry 31, 553-575.

Weber, F., 1968. Une série précambrienne du Gabon: le Francevillien. Sédimentologie, géochimie, relations avec les gîtes minéraux associés., Mém. Serv. Carte Géol. Als. Lorr.

Weber, F., Gauthier-Lafaye, F., Whitechurch, H., Ulrich, M., El Albani, A., 2016. The 2-Ga Eburnean Orogeny in Gabon and the opening of the Francevillian intracratonic basins: A review. Comptes Rendus Geoscience 348, 572-586.

Wenrich, K.J., 1985. Mineralization of breccia pipes in northern Arizona. Economic Geology 80, 1722-1735. 


\section{Table captions}

Tab. 1 Metal concentration in bitumen (ppm) from LA-ICP-MS analysis. The type of bitumen (angular or nodules) and the presence of low reflectance halos are indicated.

Tab. 2 Composition of uraninite in FA sandstones determined by EPMA in weight percents of major oxides.

Tab. 3 Rare Earth Element concentrations in FA uraninites (ppm) from LA-ICPMS analysis.

Tab. 4 Composition of Fe-chlorites determined by EPMA.

\section{Figure captions}

Fig. 1. General geological map of Gabon with main palaeoproterozoic basins (adapted from Préat et al., 2011).

Fig. 2. Geological map of Franceville basin with main uranium districts (adapted from Ossa Ossa et al., 2014).

Fig. 3. Stratigraphic column of the Francevillian Series in the Franceville basin (adapted from Gauthier-Lafaye and Weber, 2003). FA, FB, FC, FD and FE formations are described in the text.

Fig. 4. Petrographic features of organic matter in FA sandstones (TL: transmitted light; RL: reflected light). a. Bitumen cemented sandstone. b. Quartz overgrowths (OG) and bitumen (Bit.) filling residual porosity. c. Bitumen nodules on the contact between detrital quartz and overgrowths. d. Massive bitumen nodule 
crosscutting detrital quartz with preserved refractory zircons (Zrn). e. Bitumen nodule and partially dissolved quartz overgrowths. f. Low reflectance halo on a bitumen nodule. g. Low reflectance halo observed with SEM-BSE. h. Rare occurrence of coexisting angular bitumen and nodules.

Fig. 5. U, S, Fe and V X-ray maps of bitumen nodules with low reflectance halos.

Fig. 6. $\mathrm{V}-\mathrm{Ni}$ and $\mathrm{Cu}-\mathrm{Fe}$ diagrams of angular bitumens and nodules in FA sandstones (LA-ICP-MS analyses).

Fig. 7. Petrographic features of association between organic matter (black), uranium (Urn, white) and sulfides in FA sandstones. a. U nano-inclusions in bitumen nodule. b. Bitumen nodule with $\mathrm{UO}_{2}$ inclusions, low reflectance rim and radial U-filled fractures. c. Bitumen nodule with elongated $\mathrm{UO}_{2}$ inclusions and barite (Brt). d. Large $\mathrm{UO}_{2}$ and $\mathrm{UO}_{2}$ crystals in the center of a bitumen nodule. Residual porosity is filled by quartz (gray). e. Bitumen nodules and fractures filled by $\mathrm{UO}_{2}$ and sulfides (mainly pyrite, Py). f. Circular fracture network $\left(\mathrm{UO}_{2}\right.$ and pyrite) connecting bitumen nodules g. Bitumen nodule with $\mathrm{UO}_{2}$ inclusions, low reflectance rim and U-filled fractures (sulfides are pyrite and chalcopyrite). $\mathbf{h}$. Bitumen with fractures filled by $\mathrm{UO}_{2}$ and chalcocite $(\mathrm{Cc})$.

Fig. 8. Petrographic features of fractures in FA sandstones. a. Fracture network crosscutting detrital quartz $(\mathrm{Qtz})$ and overgrowths $(\mathrm{OG})$. b. Fractures and $\mathrm{UO}_{2}$ precipitation at the boundary between detrital quartz and overgrowths. c. $\mathrm{UO}_{2}$ precipitation on clays and at the boundary between detrital quartz and overgrowths. d. Detail of $\mathrm{UO}_{2}$ and illites. e. Fractures filled by $\mathrm{UO}_{2}$ and pyrite. $\mathbf{f}$. Fractures filled by $\mathrm{UO}_{2}$ and pyrite. 
Fig. 9. $\mathrm{U}+\mathrm{Ca}$ vs $\mathrm{Si}+\mathrm{P}$ and $\mathrm{Ca}+\mathrm{P}$ vs $\mathrm{U}+\mathrm{Si}$ diagrams of uranium mineralization in FA sandstones (APFU Atoms Per Formula Unit). U1, U2 and U3 are represented by triangles, squares and circles, respectively.

Fig. 10. REE patterns in U1, U2 and U3 uraninites from Mikouloungou, Bangombé and Oklo-Okélobondo locations.

Fig. 11. $\Sigma$ REE vs $(\Sigma \text { LREE / } \Sigma \text { HREE })_{\mathrm{N}}$ and Eu/Eu* vs Y/ $\Sigma$ REE diagrams in U1, U2 and U3 uraninites from Mikouloungou, Bangombé and Oklo-Okélobondo locations.

Fig. 12. 3D views from X-ray tomography on samples from Okélobondo (a to d) and Bangombé (e and f). U1-U2 are in orange, U3 in yellow and bitumen nodules are in transparent white. One video of 3D reconstruction can be downloaded from supplementary materials.

Fig. 13. $\mathrm{Fe} /(\mathrm{Fe}+\mathrm{Mg})$ vs $\mathrm{Si}$ and $\mathrm{Al}(\mathrm{VI})$ vs $\mathrm{Al}(\mathrm{IV})$ diagrams for $\mathrm{Fe}$-chlorites in Oklo-Okélobondo (green triangles), Bangombé (red squares) and Mikouloungou (blue dots) samples.

Fig. 14. Si vs $\mathrm{R}^{2+}$ diagram (Bourdelle \& Cathelineau, 2015) for Fe-chlorites in Oklo-Okélobondo (green triangles), Bangombé (red squares) and Mikouloungou (blue dots) samples.

Fig. 15. Summary diagram of oil migration and uranium mineralization in FA sandstones. Additional age data are summarized in Gauthier-Lafaye (2006). Orogeny ages are from Feybesse et al., 1998 and Thiéblemont et al., 2009.A complete list of previous data can be found in Mathieu (1999). 
Tab. 1 Metal concentration in bitumen (ppm) from LA-ICP-MS analysis. The type of bitumen (angular or nodules) and the presence of low reflectance halos are indicated.

\begin{tabular}{|c|c|c|c|c|c|c|c|c|c|}
\hline Location & Type & Point & $\begin{array}{c}S \\
p p m\end{array}$ & $\begin{array}{c}\mathrm{Ti} \\
\mathrm{ppm}\end{array}$ & $\begin{array}{c}V \\
p p m\end{array}$ & $\begin{array}{c}\text { Mn } \\
\text { ppm }\end{array}$ & $\begin{array}{c}F e \\
\text { ppm }\end{array}$ & $\begin{array}{c}\mathrm{Ni} \\
\text { ppm }\end{array}$ & $\begin{array}{c}\text { Cu } \\
\text { ppm }\end{array}$ \\
\hline Bangombé & Nodule (core) & 1 & 19546 & 8167 & 378 & 978 & 8721 & 42 & 73 \\
\hline Bangombé & Nodule (core) & 2 & 5725 & 2630 & 252 & 987 & 8688 & 24 & 196 \\
\hline Bangombé & Nodule (core) & 3 & 3234 & 1255 & 41 & 207 & 1288 & n.d. & 21 \\
\hline Bangombé & Nodule (core) & 4 & 2443 & 571 & 26 & 119 & 2603 & n.d. & 120 \\
\hline Bangombé & Nodule (halo) & 5 & 56701 & 1927 & 2005 & 1126 & 74915 & 392 & 91610 \\
\hline Bangombé & Nodule (halo) & 6 & 11617 & 41 & 1164 & 138 & 9432 & 74 & 19192 \\
\hline Lastourville & Angular bitumen (core) & 7 & 13466 & 65 & 81 & 10 & 271 & 755 & 6 \\
\hline Lastourville & Angular bitumen (core) & 8 & 9078 & 4 & 65 & 2 & 206 & 1254 & 3 \\
\hline Lastourville & Angular bitumen (core) & 9 & 7749 & 6 & 35 & n.d. & 34 & 589 & 1 \\
\hline Lastourville & Angular bitumen (core) & 10 & 5801 & 2 & 30 & n.d. & 22 & 497 & 1 \\
\hline Leyou & Nodule (core) & 11 & 5666 & 422 & 147 & 83 & 670 & 10 & 3 \\
\hline Leyou & Nodule (core) & 12 & 5445 & 42 & 1728 & 293 & 33979 & 13 & 16 \\
\hline Leyou & Nodule (core) & 13 & 8829 & 20 & 3662 & 104 & 1367 & 22 & n.d. \\
\hline Leyou & Nodule (core) & 14 & 10335 & 79 & 6343 & 203 & 1267 & 26 & 1 \\
\hline Leyou & Nodule (core) & 15 & 5671 & 404 & 125 & 141 & 496 & 3 & 3 \\
\hline Leyou & Nodule (core) & 16 & 6409 & 484 & 446 & 144 & 6561 & 6 & 3 \\
\hline Leyou & Nodule (core) & 17 & 7407 & 269 & 5812 & 941 & 1173 & n.d. & 14 \\
\hline Leyou & Nodule (halo) & 18 & 7141 & 35 & 15735 & 2029 & 1963 & 62 & 161 \\
\hline Leyou & Nodule (halo) & 19 & 4647 & 12 & 6461 & 593 & 1581 & 34 & 146 \\
\hline Leyou & Nodule (halo) & 20 & 6350 & 14 & 24313 & 582 & 6034 & 32 & 220 \\
\hline Leyou & Angular bitumen (core) & 21 & 1719 & 1 & n.d. & n.d. & 77 & 12 & 0,8 \\
\hline Leyou & Angular bitumen (core) & 22 & 2726 & 10 & n.d. & 2 & 52 & 25 & n.d. \\
\hline Leyou & Angular bitumen (core) & 23 & 2578 & 13 & 0,5 & n.d. & 275 & 24 & 3 \\
\hline Leyou & Angular bitumen (halo) & 24 & 9291 & 184 & 1485 & 1230 & 8528 & 894 & 894 \\
\hline Leyou & Angular bitumen (halo) & 25 & 18088 & 96 & 1806 & 427 & 18582 & 1721 & 1721 \\
\hline
\end{tabular}


Tab. 2 Composition of uraninite in FA sandstones determined by EPMA in weight percents of major oxides.

\begin{tabular}{|c|c|c|c|c|c|c|c|c|c|c|c|c|}
\hline Location & Point & $\mathrm{SiO}_{2}$ & $\mathrm{P}_{2} \mathrm{O}_{5}$ & $\mathrm{CaO}$ & $\mathrm{TiO}_{2}$ & $\mathrm{~V}_{2} \mathrm{O}_{3}$ & $\mathrm{FeO}$ & $\mathrm{PbO}$ & $\mathrm{ThO}_{2}$ & $\mathrm{UO}_{2}$ & $\mathrm{ZrO}_{2}$ & Total \\
\hline Mikouloungou & 1 & 0.91 & 0 & 4.32 & 1.02 & 0.07 & 0.57 & 5.53 & 0.41 & 83.23 & 0.02 & 96.08 \\
\hline Mikouloungou & 2 & 6.03 & 0.24 & 5.1 & 0.89 & 0.28 & 2.1 & 1.4 & 0 & 75.8 & 0.1 & 91.94 \\
\hline Mikouloungou & 3 & 0.89 & 0.07 & 4.51 & 1.02 & 0.16 & 0.68 & 4.74 & 0.12 & 84.67 & 0.32 & 97.18 \\
\hline Mikouloungou & 4 & 0.93 & 0.12 & 4.83 & 1.02 & 0.21 & 0.98 & 4.3 & 0.27 & 85.25 & 0.56 & 98.47 \\
\hline Mikouloungou & 5 & 1.11 & 0.04 & 4.26 & 1.01 & 0 & 0.49 & 5.84 & 0 & 84.93 & 0.38 & 98.06 \\
\hline Mikouloungou & 6 & 0.78 & 0.06 & 3.97 & 0.94 & 0.05 & 0.64 & 4.52 & 0 & 85.54 & 0.29 & 96.79 \\
\hline Mikouloungou & 7 & 7.58 & 0.22 & 4.48 & 2.27 & 0.09 & 1.33 & 2.61 & 0.07 & 74.33 & 0.95 & 93.93 \\
\hline Mikouloungou & 9 & 0.92 & 0.11 & 4.55 & 1.15 & 0.07 & 0.74 & 4.43 & 0.25 & 83.72 & 0.09 & 96.03 \\
\hline Mikouloungou & 10 & 0.84 & 0.07 & 4.22 & 0.93 & 0.08 & 0.61 & 4.73 & 0.12 & 84.64 & 0.2 & 96.44 \\
\hline Mikouloungou & 11 & 1.2 & 0.05 & 4.9 & 0.61 & 0.12 & 1.43 & 2.03 & 0 & 85.43 & 0.54 & 96.31 \\
\hline Mikouloungou & 12 & 1.26 & 0.02 & 4.21 & 0.56 & 0 & 0.44 & 5.96 & 0.01 & 83.83 & 0.21 & 96.5 \\
\hline Mikouloungou & 13 & 1.13 & 0.2 & 5.52 & 0.7 & 0.29 & 1.69 & 0.77 & 1.28 & 84.27 & 0.33 & 96.18 \\
\hline Mikouloungou & 14 & 1.77 & 0.22 & 5.55 & 0.78 & 0.28 & 1.65 & 0.93 & 0.03 & 82.85 & 0.2 & 94.26 \\
\hline Mikouloungou & 15 & 1.28 & 0.02 & 3.96 & 0.17 & 0.05 & 0.58 & 5.97 & 0.15 & 83.39 & 0.1 & 95.67 \\
\hline Mikouloungou & 16 & 1.33 & 0.03 & 4.36 & 0.14 & 0 & 0.42 & 6.22 & 0.18 & 84.53 & 0.11 & 97.32 \\
\hline Mikouloungou & 18 & 2.99 & 0.52 & 6.87 & 0.06 & 0.35 & 1.53 & 0.54 & 0 & 79.71 & 0.02 & 92.59 \\
\hline Mikouloungou & 19 & 4.45 & 0.04 & 3.75 & 0.11 & 0.11 & 0.94 & 4.49 & 0 & 76.92 & 0.4 & 91.21 \\
\hline Mikouloungou & 20 & 3.24 & 0.3 & 3.95 & 0.07 & 0.36 & 0.73 & 0 & 0 & 83.45 & 1.7 & 93.8 \\
\hline Mikouloungou & 21 & 2.68 & 0.24 & 3.49 & 0.62 & 0.42 & 1.02 & 0.25 & 0.19 & 84.43 & 2.22 & 95.56 \\
\hline Mikouloungou & 22 & 3.79 & 0.07 & 3.86 & 0.48 & 0 & 0.49 & 5.04 & 0 & 80.87 & 0.28 & 94.88 \\
\hline Mikouloungou & 23 & 1.79 & 0 & 3.81 & 0.71 & 0.09 & 0.41 & 5.34 & 0 & 82.85 & 0.46 & 95.46 \\
\hline Mikouloungou & 24 & 2.87 & 0.45 & 2.69 & 0 & 0.29 & 0.83 & 1.62 & 0 & 85.5 & 0.15 & 94.4 \\
\hline Mikouloungou & 25 & 3.75 & 0.19 & 2.51 & 0 & 0.04 & 0.88 & 2.82 & 0 & 83.54 & 0.28 & 94.01 \\
\hline Mikouloungou & 26 & 3.59 & 0.41 & 3.46 & 0 & 0.11 & 0.84 & 1.89 & 0 & 83.12 & 0.29 & 93.71 \\
\hline Mikouloungou & 27 & 3.75 & 1.3 & 2.18 & 0 & 0.15 & 0.65 & 2.81 & 0 & 79.33 & 0.68 & 90.85 \\
\hline Mikouloungou & 28 & 2.58 & 0.31 & 3.42 & 0 & 0.21 & 1 & 1.44 & 0 & 86.76 & 0.15 & 95.87 \\
\hline Mikouloungou & 29 & 2.56 & 0.34 & 3.22 & 0.02 & 0.27 & 0.94 & 1.07 & 0 & 84.62 & 0.52 & 93.56 \\
\hline Mikouloungou & 30 & 5.75 & 0.25 & 5.99 & 0 & 0.15 & 0.08 & 1.3 & 0 & 84.28 & 0.37 & 98.17 \\
\hline Mikouloungou & 31 & 4.78 & 0.26 & 5.42 & 0.29 & 0.42 & 0.26 & 1.6 & 0 & 82.51 & 0 & 95.54 \\
\hline Mikouloungou & 32 & 1 & 0.13 & 5.15 & 0 & 0.53 & 0.91 & 3.09 & 0 & 85.81 & 0.18 & 96.8 \\
\hline Mikouloungou & 35 & 0.8 & 0.01 & 4.53 & 0.31 & 0.09 & 0.65 & 3.89 & 0 & 84.67 & 0.31 & 95.26 \\
\hline Mikouloungou & 36 & 6.38 & 0.38 & 4.32 & 0.1 & 0.51 & 0.69 & 1.7 & 0 & 74.87 & 0.25 & 89.2 \\
\hline Mikouloungou & 37 & 4.7 & 0.38 & 5.04 & 0 & 0.48 & 0 & 1.49 & 0 & 80.24 & 1.1 & 93.43 \\
\hline Mikouloungou & 38 & 8.16 & 0.47 & 4.53 & 0.19 & 0.37 & 0.01 & 0.98 & 0 & 73.26 & 0.7 & 88.67 \\
\hline Mikouloungou & 39 & 1.49 & 0.08 & 4.36 & 0.75 & 0.23 & 0.69 & 2.64 & 0.19 & 84.61 & 0.58 & 95.62 \\
\hline Mikouloungou & 40 & 4.84 & 0.38 & 4.65 & 0.63 & 0.54 & 0.85 & 1.15 & 0 & 76.81 & 0.31 & 90.16 \\
\hline Mikouloungou & 41 & 3.26 & 0.17 & 5.19 & 0.5 & 0.4 & 1.06 & 0.37 & 0.02 & 86.64 & 0.51 & 98.12 \\
\hline Mikouloungou & 42 & 1.6 & 0.07 & 4.52 & 0 & 0.17 & 0.46 & 5.84 & 0 & 83.22 & 0.92 & 96.8 \\
\hline Okélobondo & 43 & 1.62 & 0.13 & 2.93 & 1.32 & 0.41 & 0.46 & 0.83 & 0.36 & 88.78 & 0.15 & 96.99 \\
\hline Okélobondo & 44 & 2.57 & 0.18 & 2.54 & 1.3 & 0.27 & 0.3 & 1.03 & 0 & 86.48 & 0.23 & 94.9 \\
\hline Okélobondo & 45 & 5.63 & 0.26 & 1.67 & 0.59 & 0.29 & 0.49 & 0.5 & 0 & 79.21 & 0 & 88.64 \\
\hline Okélobondo & 46 & 0.78 & 0 & 2.9 & 0.54 & 0.04 & 0.59 & 5.36 & 0 & 87.69 & 0 & 97.9 \\
\hline Okélobondo & 47 & 1.04 & 0.05 & 2.7 & 0.72 & 0.02 & 0.5 & 3.69 & 0 & 87.73 & 0.19 & 96.64 \\
\hline Okélobondo & 48 & 1.04 & 0.05 & 3.01 & 0.71 & 0.04 & 0.47 & 5.58 & 0.01 & 87.91 & 0 & 98.82 \\
\hline Okélobondo & 49 & 1.02 & 0.09 & 2.55 & 0.74 & 0.04 & 0.57 & 3.33 & 0.05 & 89.48 & 0.25 & 98.12 \\
\hline Okélobondo & 50 & 1.48 & 0.02 & 2.94 & 0.28 & 0.08 & 0.42 & 4.78 & 0 & 86.95 & 0.17 & 97.12 \\
\hline Okélobondo & 51 & 0.93 & 0.02 & 3.06 & 0.3 & 0.04 & 0.45 & 6.21 & 0 & 87.26 & 0 & 98.27 \\
\hline Okélobondo & 52 & 1.47 & 0.14 & 2.24 & 1.05 & 0 & 0.84 & 4.68 & 0 & 87.04 & 0 & 97.46 \\
\hline Okélobondo & 53 & 0.66 & 0.13 & 2.48 & 0.18 & 0.04 & 0.46 & 6.4 & 0.08 & 85.85 & 0.14 & 96.42 \\
\hline Okélobondo & 54 & 6.69 & 0.19 & 2.82 & 0.4 & 0.08 & 2.01 & 0.8 & 0.21 & 83.67 & 0 & 96.87 \\
\hline Okélobondo & 55 & 1.92 & 0.25 & 3.11 & 0.44 & 0.14 & 1.03 & 2.98 & 0 & 85.85 & 0 & 95.72 \\
\hline Okélobondo & 56 & 3.01 & 0.27 & 2.73 & 0.4 & 0.02 & 1.2 & 1.98 & 0.01 & 85.68 & 0.1 & 95.4 \\
\hline Okélobondo & 57 & 0.88 & 0.11 & 2.24 & 0.8 & 0 & 0.54 & 4.05 & 0.04 & 87.66 & 0 & 96.32 \\
\hline Bangombé & 58 & 0.43 & 1.03 & 1.42 & 1.2 & 0 & 0.92 & 5.13 & 0 & 83.51 & 0.12 & 93.76 \\
\hline Bangombé & 59 & 1.02 & 0.13 & 1.72 & 0.49 & 0.09 & 0.94 & 5.71 & 0 & 85.8 & 0.23 & 96.13 \\
\hline
\end{tabular}


Tab. 3 Rare Earth Element concentrations in FA uraninites (ppm) from LA-ICPMS analysis.

\begin{tabular}{|c|c|c|c|c|c|c|c|c|c|c|c|c|c|c|c|c|}
\hline Location & Point & $\begin{array}{c}Y \\
\text { ppm }\end{array}$ & $\begin{array}{c}\text { La } \\
\text { ppm }\end{array}$ & $\begin{array}{c}C e \\
p p m\end{array}$ & $\begin{array}{c}P r \\
\text { ppm }\end{array}$ & $\begin{array}{c}N d \\
p p m\end{array}$ & $\begin{array}{c}\text { Sm } \\
\text { ppm }\end{array}$ & $\begin{array}{c}E u \\
\text { ppm }\end{array}$ & $\begin{array}{c}G d \\
p p m\end{array}$ & $\begin{array}{c}T b \\
\text { ppm } \\
\end{array}$ & $\begin{array}{c}D y \\
\text { ppm }\end{array}$ & $\begin{array}{c}\text { Ho } \\
\text { ppm }\end{array}$ & $\begin{array}{c}E r \\
p p m\end{array}$ & $\begin{array}{c}T m \\
\text { ppm }\end{array}$ & $\begin{array}{c}Y b \\
\text { ppm }\end{array}$ & $\begin{array}{c}\mathrm{Lu} \\
\mathrm{ppm}\end{array}$ \\
\hline Mikou. & 1 & 2124 & 712 & 3512 & 621 & 3460 & 857 & 230 & 820 & 71 & 291 & 47 & 87 & 7 & 32 & 4 \\
\hline Mikou. & 2 & 2768 & 945 & 4333 & 684 & 3425 & 823 & 296 & 922 & 73 & 301 & 46 & 86 & 6 & 33 & 4 \\
\hline Mikou. & 3 & 1431 & 1141 & 4424 & 700 & 2999 & 654 & 280 & 607 & 45 & 177 & 24 & 48 & 3 & 17 & 2 \\
\hline Mikou. & 4 & 1980 & 959 & 4299 & 710 & 3676 & 798 & 313 & 774 & 66 & 267 & 43 & 82 & 6 & 29 & 4 \\
\hline Mikou. & 5 & 1195 & 834 & 3252 & 497 & 2450 & 540 & 189 & 495 & 43 & 178 & 28 & 51 & 4 & 19 & 3 \\
\hline Mikou. & 6 & 1567 & 863 & 3703 & 569 & 2887 & 674 & 297 & 628 & 55 & 224 & 35 & 68 & 5 & 25 & 3 \\
\hline Oklo & 7 & 176 & 176 & 1722 & 300 & 1334 & 253 & 102 & 175 & 16 & 62 & 8 & 17 & 1 & 8 & 0.8 \\
\hline Oklo & 8 & 137 & 292 & 1863 & 254 & 990 & 190 & 61 & 132 & 13 & 52 & 7 & 14 & 1 & 7 & 0.8 \\
\hline Oklo & 9 & 130 & 264 & 1592 & 219 & 847 & 162 & 51 & 112 & 11 & 44 & 6 & 12 & 1 & 6 & 0.7 \\
\hline Oklo & 10 & 181 & 261 & 1484 & 209 & 804 & 175 & 54 & 144 & 14 & 57 & 8 & 16 & 2 & 7 & 0.9 \\
\hline Oklo & 11 & 368 & 270 & 1867 & 274 & 1152 & 263 & 84 & 240 & 24 & 95 & 13 & 28 & 2 & 12 & 2 \\
\hline Oklo & 12 & 203 & 233 & 1504 & 265 & 1213 & 263 & 84 & 181 & 16 & 65 & 9 & 17 & 2 & 8 & 0.9 \\
\hline Okélo. & 13 & 192 & 8 & 174 & 60 & 345 & 206 & 68 & 178 & 16 & 56 & 6 & 10 & 0.9 & 5 & 0.5 \\
\hline Okélo. & 14 & 179 & 21 & 387 & 126 & 623 & 244 & 47 & 176 & 19 & 69 & 7 & 11 & 1 & 7 & 0.5 \\
\hline Okélo. & 15 & 198 & 9 & 137 & 44 & 283 & 300 & 54 & 221 & 24 & 85 & 8 & 15 & 1 & 9 & 0.8 \\
\hline Okélo. & 16 & 193 & 14 & 294 & 96 & 521 & 296 & 47 & 230 & 20 & 85 & 6 & 14 & 0.8 & 10 & 0.7 \\
\hline Okélo. & 17 & 176 & 9 & 207 & 70 & 373 & 256 & 43 & 194 & 20 & 75 & 8 & 13 & 1 & 8 & 0.7 \\
\hline Okélo. & 18 & 214 & 7 & 148 & 50 & 308 & 202 & 60 & 199 & 18 & 59 & 6 & 10 & 1 & 5 & 0.5 \\
\hline Okélo. & 19 & 160 & 11 & 249 & 84 & 423 & 177 & 45 & 158 & 15 & 54 & 5 & 9 & 0.9 & 6 & 0.5 \\
\hline Okélo. & 20 & 175 & 11 & 214 & 60 & 327 & 247 & 50 & 190 & 19 & 68 & 7 & 12 & 1 & 8 & 0.7 \\
\hline Okélo. & 21 & 218 & 7 & 164 & 52 & 304 & 211 & 62 & 208 & 20 & 70 & 7 & 11 & 1 & 6 & 0.6 \\
\hline Okélo. & 22 & 194 & 10 & 186 & 61 & 333 & 220 & 57 & 188 & 18 & 63 & 7 & 11 & 1 & 6 & 0.6 \\
\hline Okélo. & 23 & 177 & 11 & 221 & 68 & 364 & 200 & 56 & 177 & 18 & 63 & 6 & 11 & 1 & 5 & 0.7 \\
\hline Okélo. & 24 & 127 & 14 & 272 & 98 & 506 & 180 & 40 & 129 & 13 & 46 & 5 & 9 & 0.9 & 5 & 0.6 \\
\hline Mikou. & 25 & 1854 & 765 & 2390 & 357 & 1732 & 660 & 57 & 673 & 80 & 378 & 59 & 118 & 9 & 46 & 7 \\
\hline Mikou. & 26 & 747 & 531 & 1760 & 260 & 1318 & 361 & 36 & 297 & 32 & 147 & 21 & 42 & 3 & 18 & 2 \\
\hline Mikou. & 27 & 1621 & 736 & 2843 & 464 & 2296 & 637 & 108 & 596 & 63 & 272 & 42 & 82 & 7 & 32 & 4 \\
\hline Mikou. & 28 & 629 & 495 & 1345 & 173 & 744 & 255 & 14 & 226 & 27 & 130 & 20 & 39 & 3 & 17 & 2 \\
\hline Okélo. & 29 & 63 & 28 & 434 & 137 & 606 & 133 & 18 & 66 & 7 & 29 & 3 & 6 & 0.6 & 5 & 0.5 \\
\hline Okélo. & 30 & 73 & 23 & 370 & 122 & 568 & 139 & 22 & 77 & 8 & 31 & 3 & 6 & 0.7 & 4 & 0.5 \\
\hline Okélo. & 31 & 133 & 35 & 502 & 149 & 658 & 177 & 15 & 109 & 12 & 47 & 5 & 11 & 1 & 7 & 0.8 \\
\hline Okélo. & 32 & 152 & 44 & 654 & 199 & 893 & 200 & 16 & 122 & 14 & 52 & 6 & 12 & 1 & 9 & 1 \\
\hline Okélo. & 33 & 101 & 28 & 386 & 114 & 469 & 138 & 30 & 101 & 10 & 35 & 3 & 6 & 0.6 & 3 & 0.5 \\
\hline Okélo. & 34 & 30 & 72 & 336 & 49 & 189 & 46 & 3 & 30 & 3 & 15 & 2 & 4 & 0.3 & 2 & 0.3 \\
\hline Okélo. & 35 & 24 & 72 & 312 & 42 & 157 & 39 & 2 & 23 & 3 & 10 & 2 & 3 & 0.3 & 2 & 0.3 \\
\hline Okélo. & 36 & 45 & 41 & 294 & 52 & 232 & 65 & 4 & 44 & 5 & 26 & 3 & 7 & 0.9 & 5 & 0.5 \\
\hline Okélo. & 37 & 33 & 60 & 338 & 51 & 211 & 51 & 3 & 33 & 4 & 16 & 2 & 4 & 0.4 & 3 & 0.4 \\
\hline Okélo. & 38 & 51 & 71 & 387 & 58 & 236 & 67 & 4 & 49 & 6 & 29 & 4 & 8 & 0.8 & 6 & 0.5 \\
\hline Okélo. & 39 & 97 & 101 & 476 & 70 & 315 & 105 & 5 & 83 & 10 & 45 & 7 & 13 & 1 & 8 & 0.7 \\
\hline Okélo. & 40 & 32 & 55 & 319 & 50 & 207 & 52 & 3 & 33 & 4 & 16 & 2 & 4 & 0.5 & 3 & 0.3 \\
\hline Okélo. & 41 & 40 & 42 & 317 & 52 & 225 & 60 & 3 & 40 & 5 & 20 & 3 & 6 & 0.6 & 4 & 0.4 \\
\hline Okélo. & 42 & 36 & 78 & 349 & 48 & 201 & 49 & 3 & 35 & 4 & 16 & 2 & 4 & 0.5 & 3 & 0.3 \\
\hline Okélo. & 43 & 44 & 45 & 356 & 57 & 235 & 64 & 4 & 47 & 5 & 21 & 3 & 5 & 0.5 & 3 & 0.4 \\
\hline Okélo. & 44 & 40 & 40 & 307 & 53 & 228 & 60 & 3 & 39 & 5 & 22 & 3 & 6 & 0.5 & 3 & 0.3 \\
\hline Okélo. & 45 & 32 & 61 & 328 & 47 & 188 & 46 & 3 & 30 & 4 & 15 & 2 & 5 & 0.4 & 2 & 0.2 \\
\hline Okélo. & 46 & 28 & 51 & 306 & 47 & 187 & 46 & 3 & 28 & 3 & 14 & 2 & 4 & 0.5 & 3 & 0.2 \\
\hline Okélo. & 47 & 54 & 54 & 363 & 60 & 257 & 68 & 5 & 48 & 5 & 24 & 3 & 7 & 0.7 & 4 & 0.4 \\
\hline Okélo. & 48 & 42 & 62 & 388 & 61 & 249 & 65 & 4 & 43 & 5 & 21 & 3 & 5 & 0.6 & 3 & 0.4 \\
\hline Okélo. & 49 & 50 & 50 & 338 & 56 & 240 & 66 & 4 & 45 & 5 & 22 & 3 & 6 & 0.6 & 4 & 0.5 \\
\hline Okélo. & 50 & 34 & 56 & 275 & 41 & 168 & 44 & 3 & 33 & 4 & 17 & 2 & 5 & 0.4 & 3 & 0.3 \\
\hline Okélo. & 51 & 68 & 31 & 317 & 58 & 269 & 75 & 5 & 58 & 7 & 26 & 4 & 8 & 0.9 & 5 & 0.6 \\
\hline Okélo. & 52 & 59 & 31 & 295 & 52 & 240 & 74 & 4 & 53 & 6 & 29 & 4 & 8 & 0.8 & 5 & 0.5 \\
\hline Bangombé & 53 & 1103 & 584 & 1360 & 136 & 508 & 87 & 22 & 136 & 12 & 67 & 15 & 43 & 5 & 28 & 5 \\
\hline Bangombé & 54 & 365 & 574 & 1119 & 100 & 316 & 40 & 9 & 53 & 5 & 26 & 5 & 14 & 1 & 9 & 2 \\
\hline Mikou. & 55 & 9 & 360 & 354 & 31 & 79 & 12 & 7 & 4 & 1 & 5 & 0.9 & 3 & 0.4 & 3 & 0.3 \\
\hline Mikou. & 56 & 31 & 459 & 441 & 38 & 102 & 12 & 8 & 7 & 1 & 6 & 1 & 3 & 0.5 & 4 & 0.4 \\
\hline Mikou. & 57 & 16 & 345 & 328 & 27 & 83 & 12 & 7 & 5 & 0.9 & 5 & 0.9 & 3 & 0.4 & 3 & 0.3 \\
\hline
\end{tabular}


Tab. 4 Composition of Fe-chlorites determined by EPMA.

\begin{tabular}{|c|c|c|c|c|c|c|c|c|c|c|c|c|c|}
\hline Location & Point & $\mathrm{Na}_{2} \mathrm{O}$ & $\mathrm{MgO}$ & $\mathrm{Al}_{2} \mathrm{O}_{3}$ & $\mathrm{SiO}_{2}$ & $\mathrm{~K}_{2} \mathrm{O}$ & $\mathrm{CaO}$ & $\mathrm{TiO}_{2}$ & $\mathrm{MnO}_{2}$ & $\mathrm{~V}_{2} \mathrm{O}_{3}$ & $\mathrm{FeO}$ & Total & $T\left({ }^{\circ} \mathrm{C}\right)$ \\
\hline Mikou. & 1 & 0.01 & 6.98 & 22.04 & 25.32 & 0.01 & 0.05 & 0 & 0.22 & 0.25 & 27.92 & 82.81 & 154 \\
\hline Mikou. & 2 & 0.02 & 7.71 & 22.47 & 24.87 & 0.02 & 0.12 & 0 & 0.14 & 0.43 & 29 & 84.79 & 196 \\
\hline Mikou. & 3 & 0.02 & 7.41 & 21.5 & 25.28 & 0 & 0.03 & 0 & 0.06 & 0.24 & 27.79 & 82.33 & 156 \\
\hline Mikou. & 4 & 0 & 9.94 & 21.68 & 24.14 & 0.1 & 0.01 & 0.03 & 0 & 0.67 & 26.72 & 83.29 & 257 \\
\hline Mikou. & 5 & 0.05 & 9.46 & 21.28 & 24.56 & 0.01 & 0.02 & 0 & 0.13 & 1.13 & 25.93 & 82.54 & 230 \\
\hline Mikou. & 6 & 0 & 6.8 & 22.89 & 24.24 & 0.03 & 0.04 & 0.01 & 0.09 & 0.65 & 27.43 & 82.19 & 180 \\
\hline Bangombé & 7 & 0.02 & 9.26 & 23.61 & 25.08 & 0.03 & 0.04 & 0 & 0.14 & 0 & 26.01 & 84.17 & 178 \\
\hline Bangombé & 8 & 0.02 & 10.62 & 23.85 & 24.41 & 0 & 0.01 & 0 & 0.12 & 0 & 25.19 & 84.23 & 216 \\
\hline Bangombé & 9 & 0 & 10.3 & 23.65 & 25.19 & 0.03 & 0 & 0 & 0.1 & 0.04 & 24.31 & 83.62 & 177 \\
\hline Bangombé & 10 & 0.02 & 9.23 & 24.07 & 23.06 & 0 & 0 & 0.01 & 0.11 & 0 & 25.71 & 82.22 & 230 \\
\hline Bangombé & 11 & 0.01 & 8.99 & 23.38 & 24.5 & 0.02 & 0.04 & 0 & 0.14 & 0.02 & 26.65 & 83.74 & 193 \\
\hline Bangombé & 12 & 0 & 10.27 & 22.9 & 23.88 & 0 & 0 & 0.01 & 0.14 & 0.04 & 25.31 & 82.55 & 223 \\
\hline Bangombé & 13 & 0.02 & 10.27 & 22.66 & 23.76 & 0.01 & 0 & 0 & 0.06 & 0.03 & 26.1 & 82.91 & 241 \\
\hline Bangombé & 14 & 0.09 & 6.86 & 22 & 23.46 & 0.02 & 0.01 & 0 & 0.12 & 0 & 29.58 & 82.15 & 205 \\
\hline Bangombé & 15 & 0 & 8.06 & 22.74 & 23.81 & 0 & 0.01 & 0 & 0.22 & 0.04 & 28.66 & 83.55 & 217 \\
\hline Bangombé & 16 & 0.04 & 6.28 & 21.47 & 24.72 & 0.07 & 0.08 & 0 & 0.12 & 0.04 & 29.27 & 82.07 & 158 \\
\hline Bangombé & 17 & 0.01 & 7.82 & 22.05 & 24.26 & 0 & 0 & 0.02 & 0.16 & 0.06 & 28.82 & 83.2 & 196 \\
\hline Bangombé & 18 & 0.14 & 8.05 & 22.17 & 23.76 & 0.03 & 0.02 & 0.01 & 0 & 0.02 & 28.87 & 83.07 & 220 \\
\hline Bangombé & 19 & 0.05 & 7.25 & 21.52 & 23.94 & 0.03 & 0.05 & 0 & 0.09 & 0 & 29.5 & 82.43 & 198 \\
\hline Bangombé & 20 & 0.01 & 6.81 & 22.19 & 23.3 & 0.02 & 0.03 & 0.02 & 0.1 & 0.08 & 30.2 & 82.76 & 221 \\
\hline Bangombé & 21 & 0.03 & 6.88 & 21.72 & 23.7 & 0 & 0.04 & 0 & 0.14 & 0.07 & 30.71 & 83.3 & 217 \\
\hline Bangombé & 22 & 0 & 8.2 & 23.04 & 24.53 & 0.03 & 0.1 & 0 & 0.12 & 0 & 26.56 & 82.58 & 174 \\
\hline Bangombé & 23 & 0.04 & 7.92 & 24.2 & 24 & 0.09 & 0.03 & 0 & 0.19 & 0.02 & 27.38 & 83.86 & 197 \\
\hline Bangombé & 24 & 0 & 9.1 & 22.78 & 24.19 & 0.03 & 0 & 0 & 0.16 & 0.02 & 26.62 & 82.91 & 201 \\
\hline Bangombé & 25 & 0.03 & 7.85 & 24.14 & 24.36 & 0.01 & 0.06 & 0.02 & 0.02 & 0 & 27.89 & 84.38 & 188 \\
\hline Bangombé & 26 & 0.01 & 8.26 & 23.55 & 23.77 & 0 & 0.05 & 0 & 0 & 0.03 & 28.24 & 83.91 & 216 \\
\hline Bangombé & 27 & 0 & 8.02 & 24.02 & 23.54 & 0.01 & 0 & 0.01 & 0.13 & 0.04 & 29.1 & 84.86 & 236 \\
\hline Bangombé & 28 & 0.01 & 8.08 & 23.62 & 24.39 & 0.02 & 0.06 & 0 & 0.05 & 0 & 28.01 & 84.25 & 192 \\
\hline Bangombé & 29 & 0.03 & 7.75 & 23.47 & 23.8 & 0.04 & 0.09 & 0 & 0.14 & 0.02 & 26.85 & 82.19 & 188 \\
\hline Bangombé & 30 & 0.05 & 9.41 & 23.12 & 24.06 & 0 & 0 & 0 & 0.17 & 0 & 27.43 & 84.25 & 228 \\
\hline Okélo. & 31 & 0.05 & 8.52 & 22.45 & 24.77 & 0.01 & 0 & 0.06 & 0.02 & 1.31 & 27.28 & 84.46 & 225 \\
\hline Okélo. & 32 & 0 & 9.52 & 22.67 & 24.65 & 0.01 & 0.09 & 0.02 & 0 & 0.94 & 25.52 & 83.42 & 214 \\
\hline Okélo. & 33 & 0.03 & 10.06 & 23.2 & 23.82 & 0 & 0.05 & 0.02 & 0.09 & 1.02 & 26.26 & 84.56 & 300 \\
\hline Okélo. & 34 & 0 & 9.07 & 21.77 & 23.47 & 0 & 0.02 & 0 & 0.18 & 1.4 & 27.21 & 83.12 & 334 \\
\hline Okélo. & 35 & 0 & 7.29 & 21.47 & 23.41 & 0 & 0.01 & 0.01 & 0.07 & 2.14 & 28.97 & 83.37 & 317 \\
\hline Okélo. & 36 & 0 & 9.65 & 22.07 & 24.07 & 0 & 0.03 & 0 & 0.16 & 1.14 & 26.84 & 83.96 & 287 \\
\hline Okélo. & 37 & 0.02 & 10.29 & 21.85 & 24.01 & 0 & 0.02 & 0 & 0.07 & 1.14 & 26.07 & 83.46 & 302 \\
\hline Okélo. & 38 & 0.02 & 5.77 & 21.22 & 23.2 & 0 & 0.06 & 0.01 & 0.15 & 2.28 & 31.18 & 83.88 & 330 \\
\hline
\end{tabular}




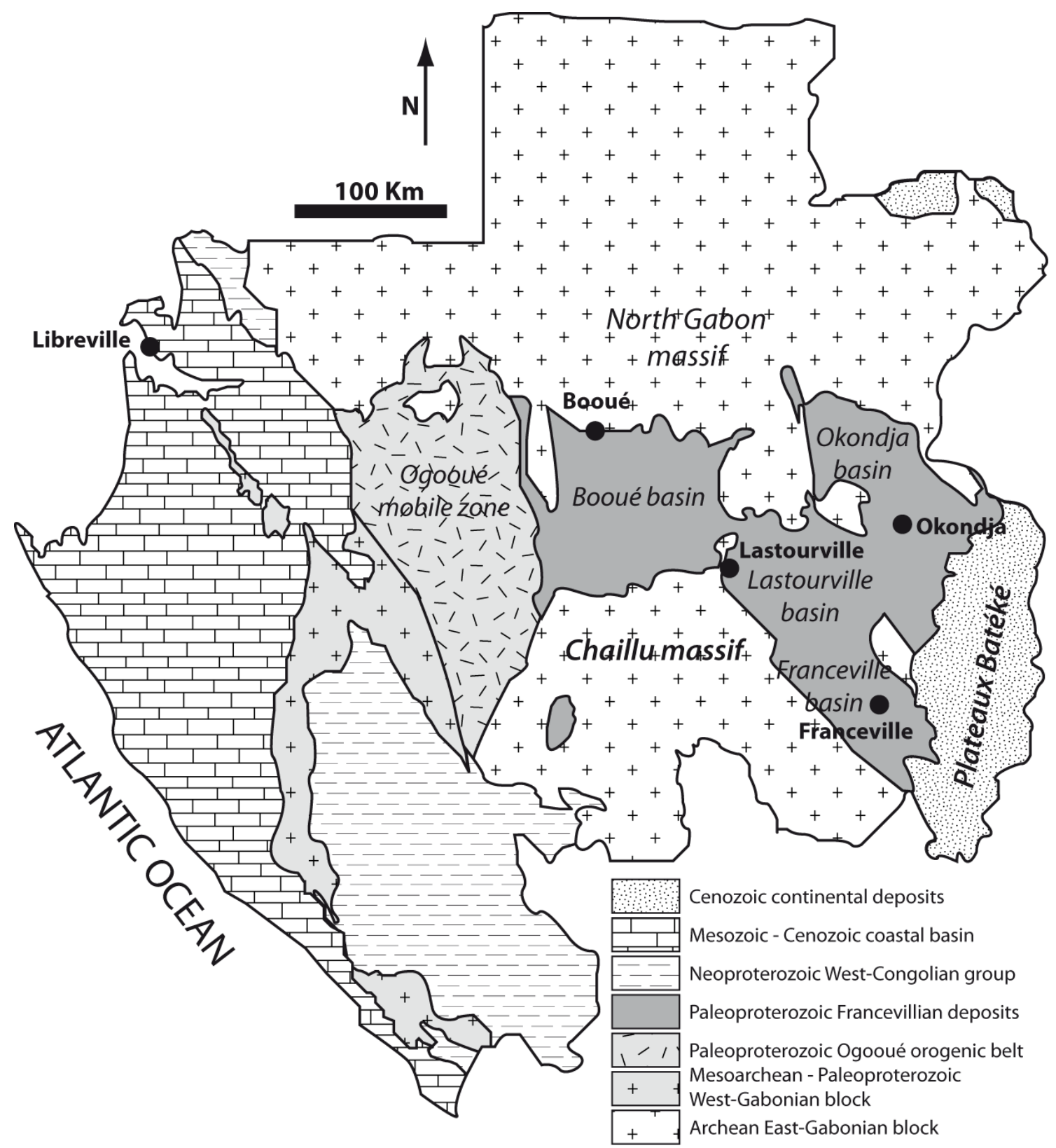

Fig. 1. General geological map of Gabon with main palaeoproterozoic basins (adapted from Préat et al., 2011). 


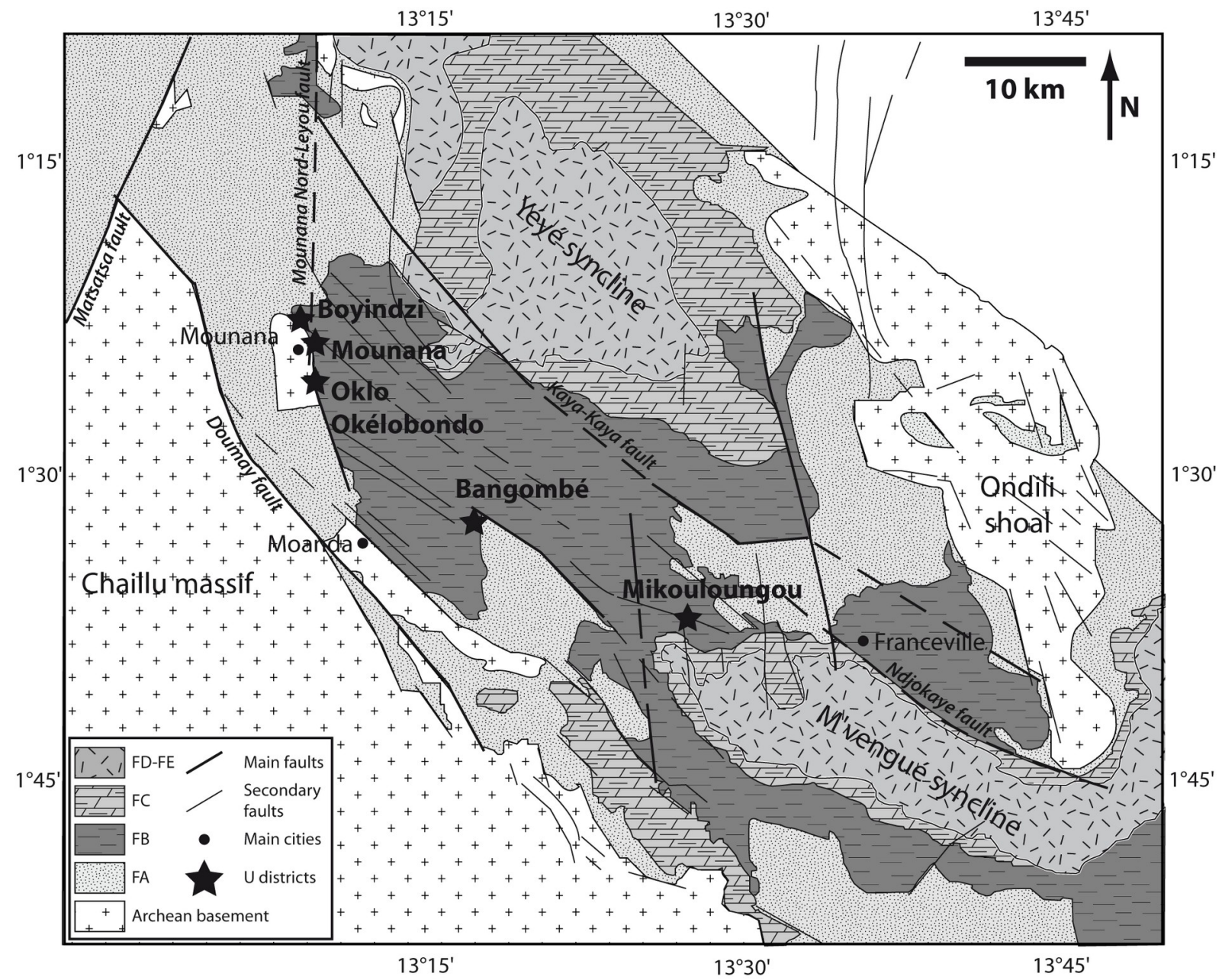

Fig. 2. Geological map of Franceville basin with main uranium districts (adapted from Ossa Ossa et al., 2014). 


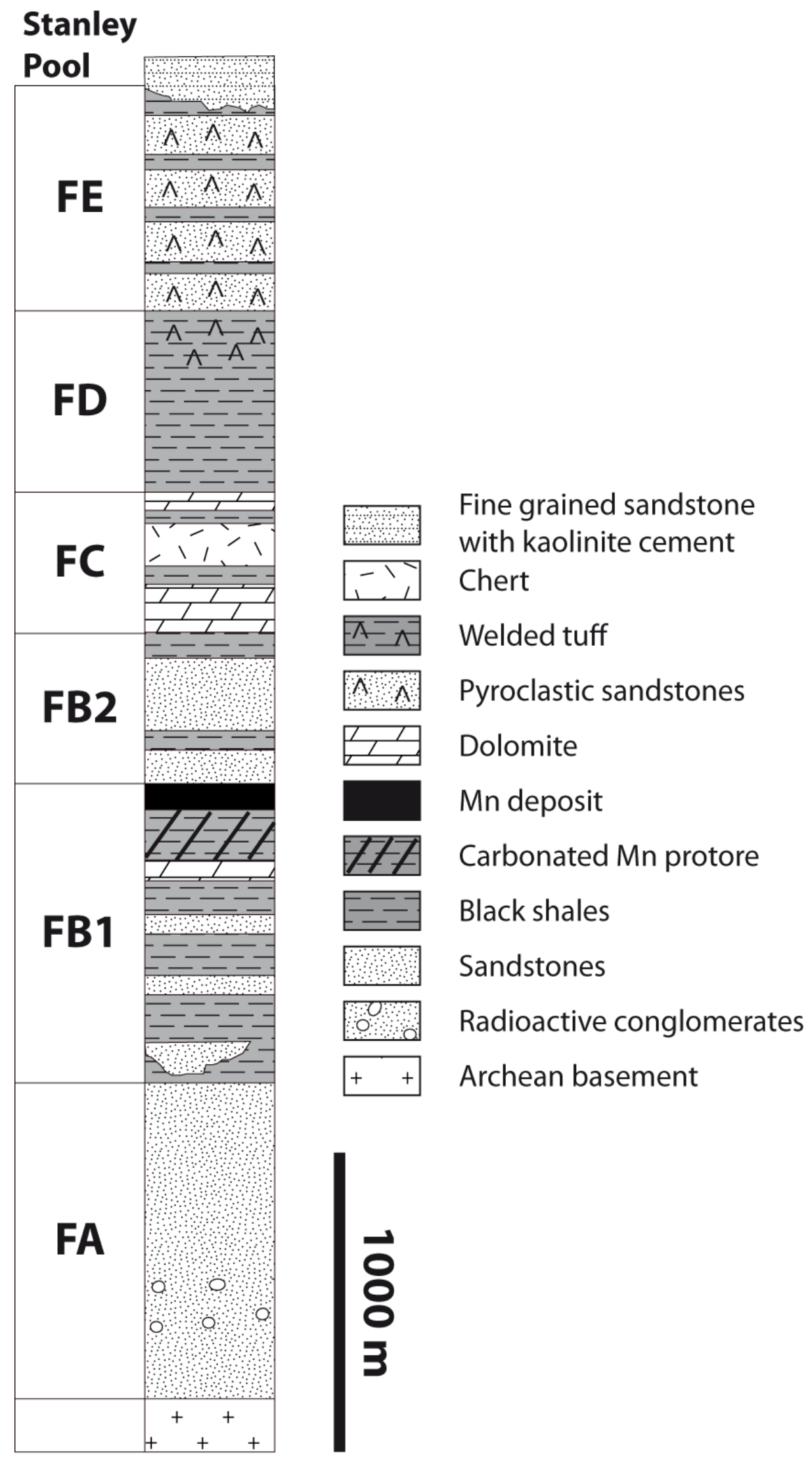

Fig. 3. Stratigraphic column of the Francevillian Series in the Franceville basin (adapted from Gauthier-Lafaye and Weber, 2003). FA, FB, FC, FD and FE formations are described in the text. 

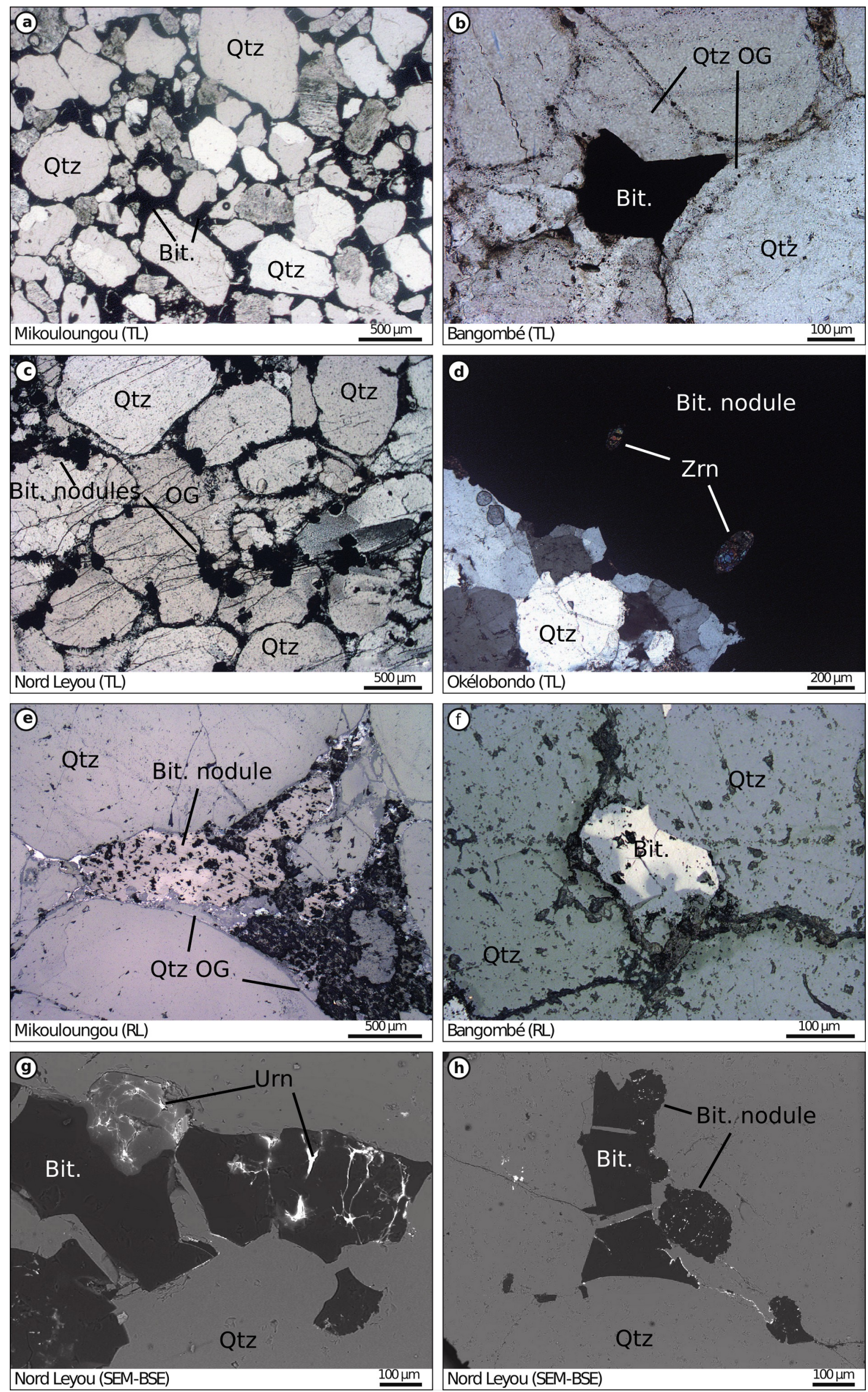
Fig. 4. Petrographic features of organic matter in FA sandstones (TL: transmitted light; RL: reflected light). a. Bitumen cemented sandstone. b. Quartz overgrowths (OG) and bitumen (Bit.) filling residual porosity. c. Bitumen nodules on the contact between detrital quartz and overgrowths. d. Massive bitumen nodule crosscutting detrital quartz with preserved refractory zircons (Zrn). e. Bitumen nodule and partially dissolved quartz overgrowths. f. Low reflectance halo on a bitumen nodule. g. Low reflectance halo observed with SEM-BSE. h. Rare occurrence of coexisting angular bitumen and nodules. 

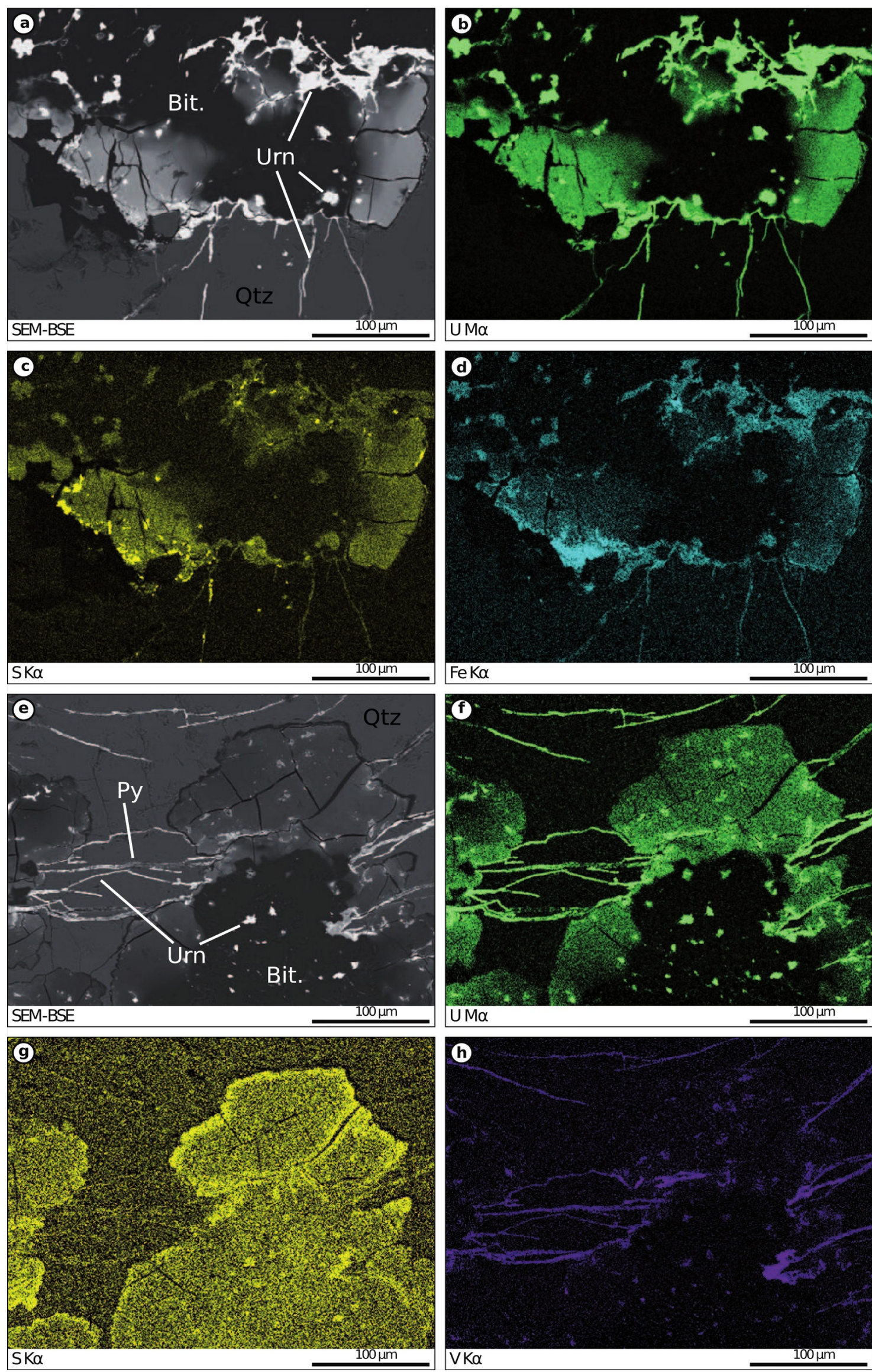

Fig. 5. U, S, Fe and V X-ray maps of bitumen nodules with low reflectance halos. 

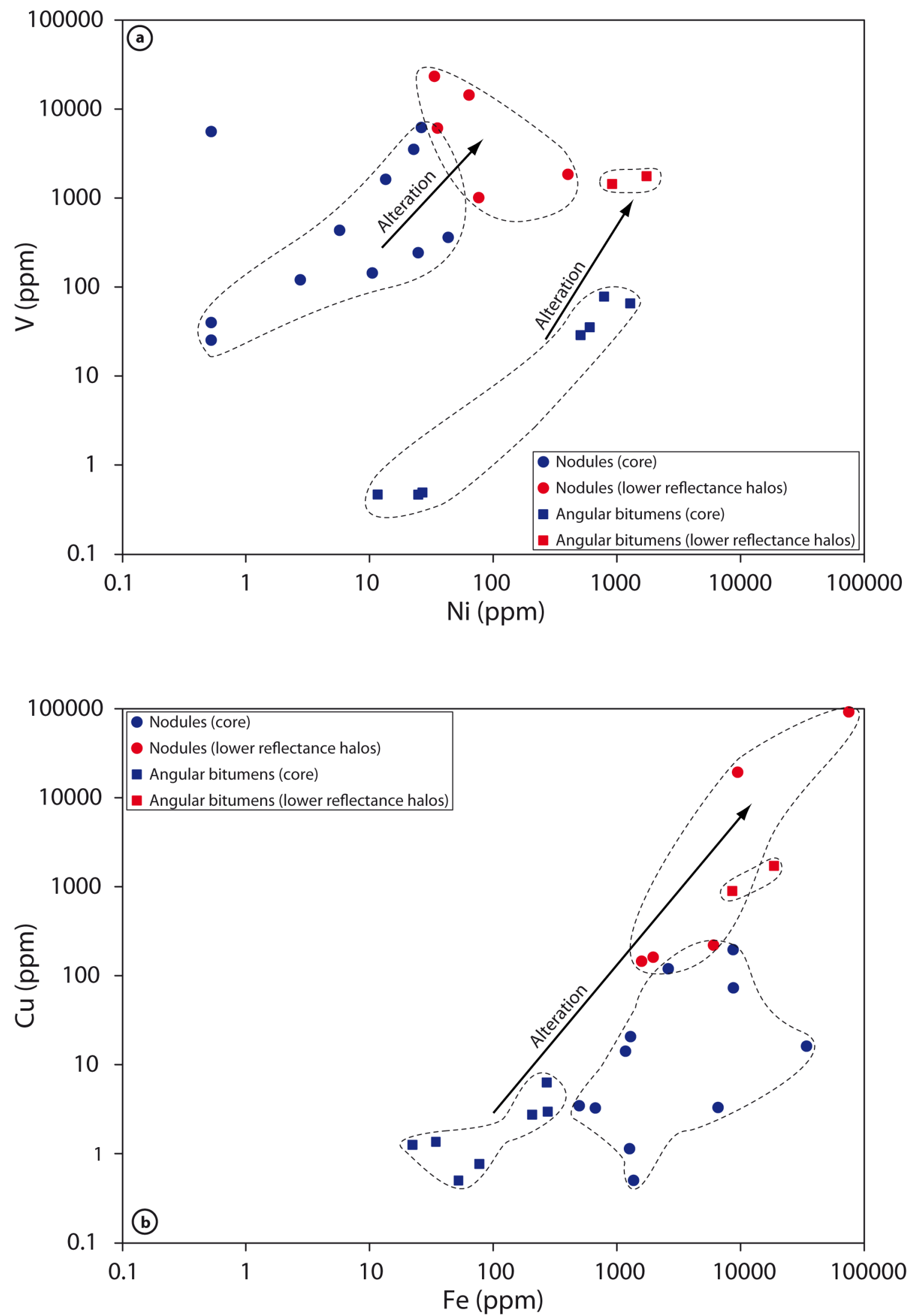

Fig. 6. $\mathrm{V}-\mathrm{Ni}$ and $\mathrm{Cu}-\mathrm{Fe}$ diagrams of angular bitumens and nodules in FA sandstones (LA-ICP-MS analyses). 

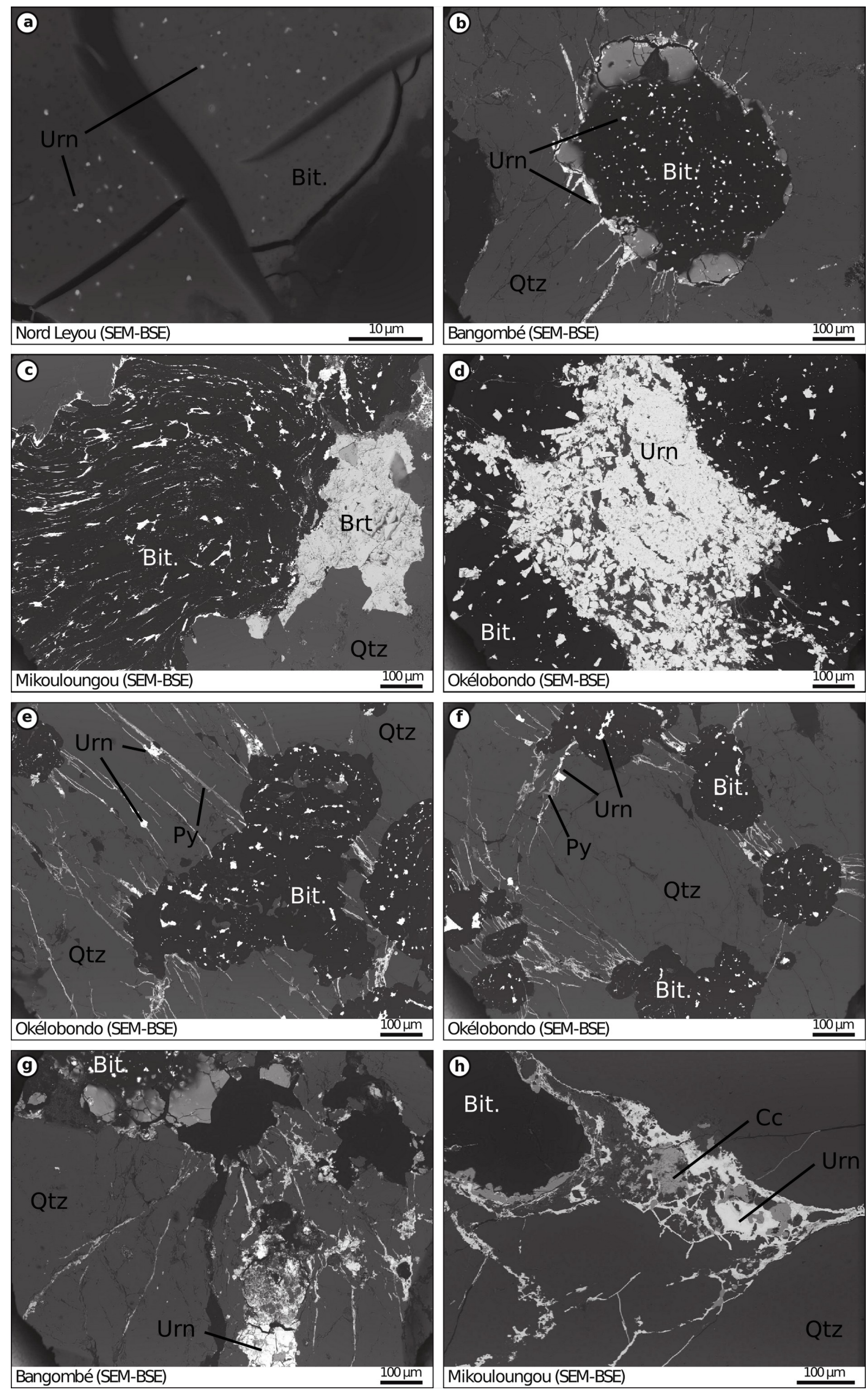
Fig. 7. Petrographic features of association between organic matter (black), uranium (Urn, white) and sulfides in FA sandstones. a. U nano-inclusions in bitumen nodule. b. Bitumen nodule with $\mathrm{UO}_{2}$ inclusions, low reflectance rim and radial U-filled fractures. c. Bitumen nodule with elongated $\mathrm{UO}_{2}$ inclusions and barite (Brt). d. Large $\mathrm{UO}_{2}$ and $\mathrm{UO}_{2}$ crystals in the center of a bitumen nodule. Residual porosity is filled by quartz (gray). e. Bitumen nodules and fractures filled by $\mathrm{UO}_{2}$ and sulfides (mainly pyrite, Py). f. Circular fracture network $\left(\mathrm{UO}_{2}\right.$ and pyrite) connecting bitumen nodules g. Bitumen nodule with $\mathrm{UO}_{2}$ inclusions, low reflectance rim and U-filled fractures (sulfides are pyrite and chalcopyrite). $\mathbf{h}$. Bitumen with fractures filled by $\mathrm{UO}_{2}$ and chalcocite $(\mathrm{Cc})$. 

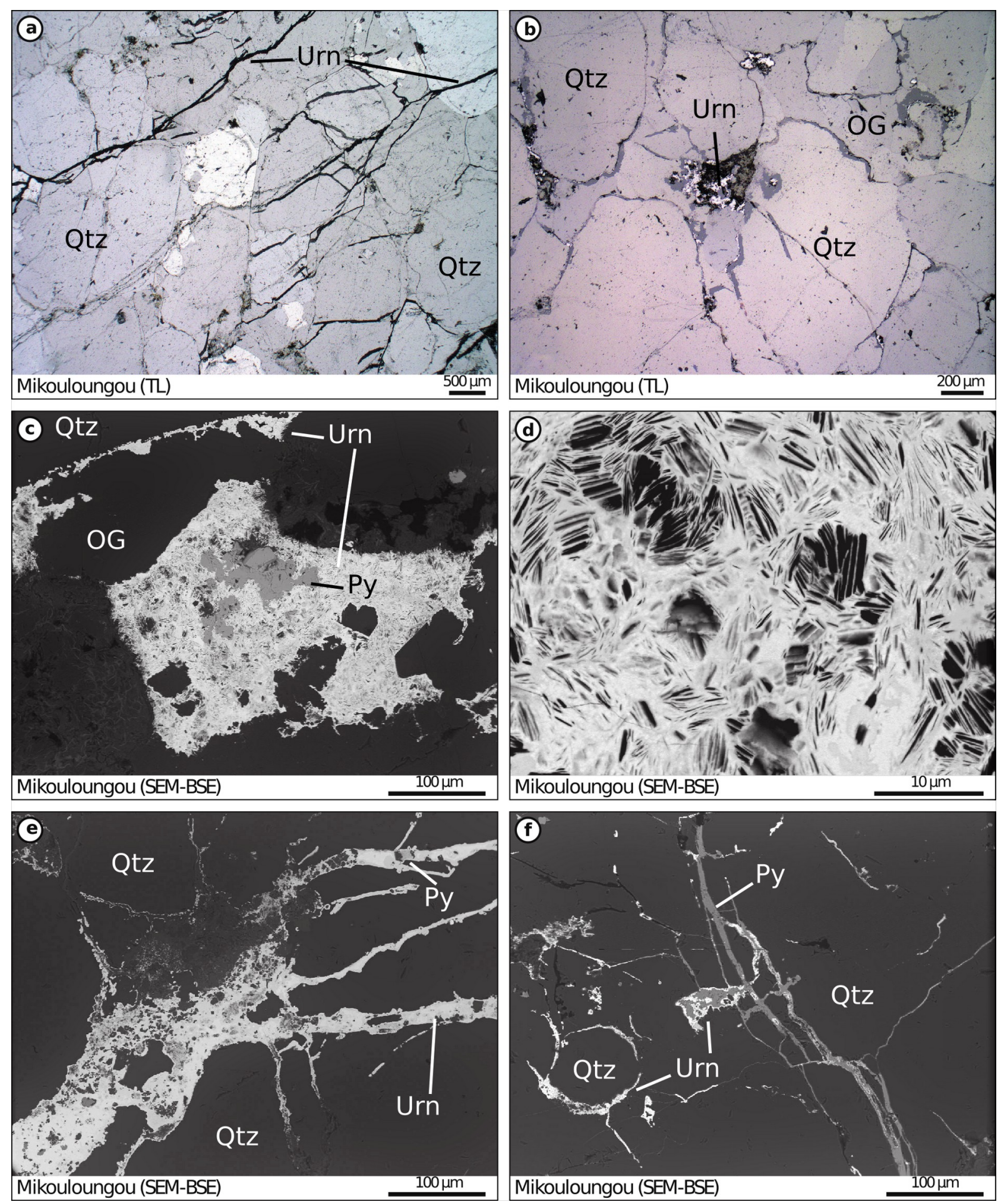

Fig. 8. Petrographic features of fractures in FA sandstones. a. Fracture network crosscutting detrital quartz (Qtz) and overgrowths (OG). b. Fractures and $\mathrm{UO}_{2}$ precipitation at the boundary between detrital quartz and overgrowths. c. $\mathrm{UO}_{2}$ precipitation on clays and at the boundary between detrital quartz and overgrowths. d. Detail of $\mathrm{UO}_{2}$ and illites. e. Fractures filled by $\mathrm{UO}_{2}$ and pyrite. f. Fractures filled by $\mathrm{UO}_{2}$ and pyrite. 

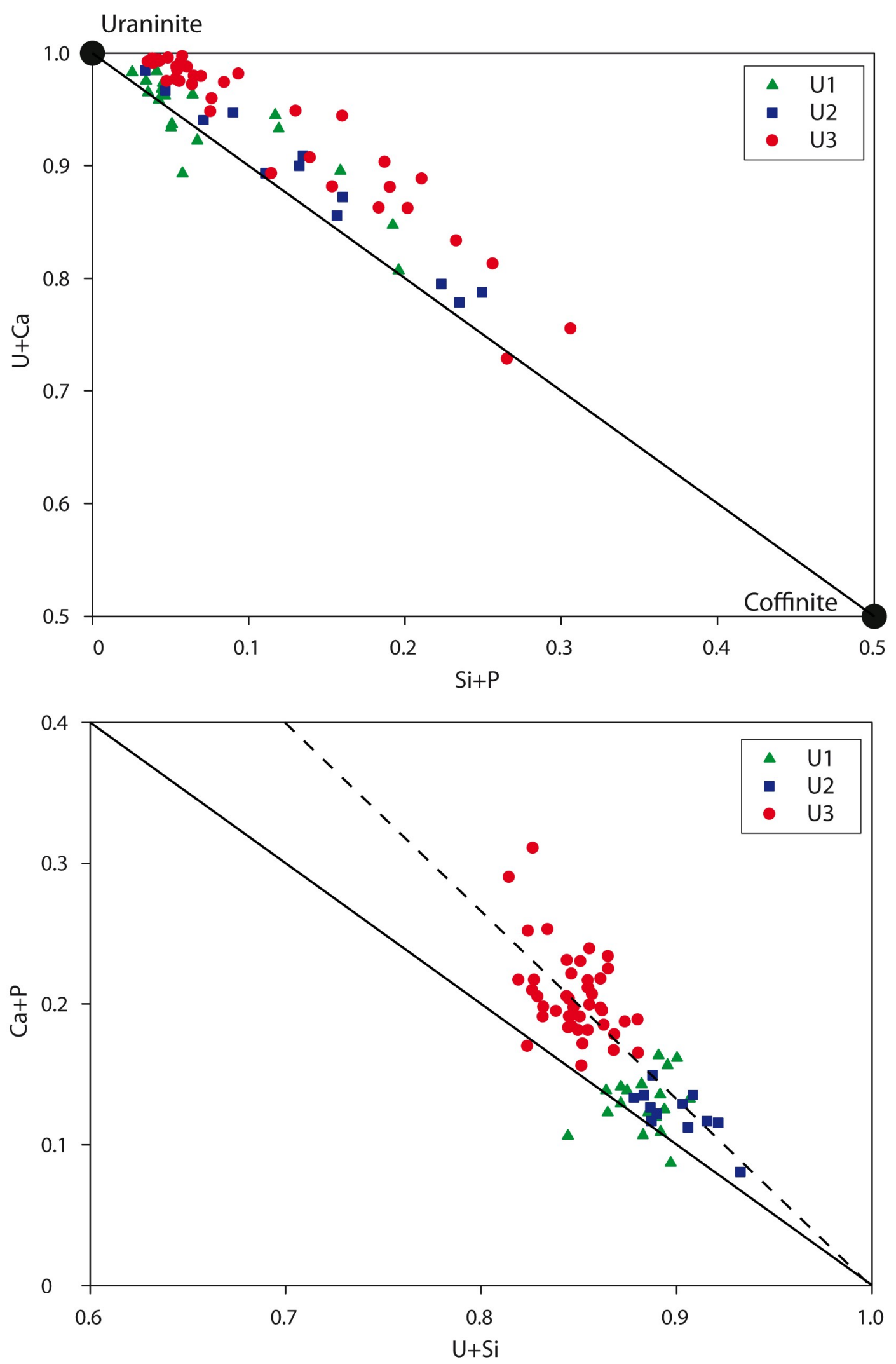

Fig. 9. $\mathrm{U}+\mathrm{Ca}$ vs $\mathrm{Si}+\mathrm{P}$ and $\mathrm{Ca}+\mathrm{P}$ vs $\mathrm{U}+\mathrm{Si}$ diagrams of uranium mineralization in FA sandstones (APFU Atoms Per Formula Unit). U1, U2 and U3 are represented by triangles, squares and circles, respectively. 

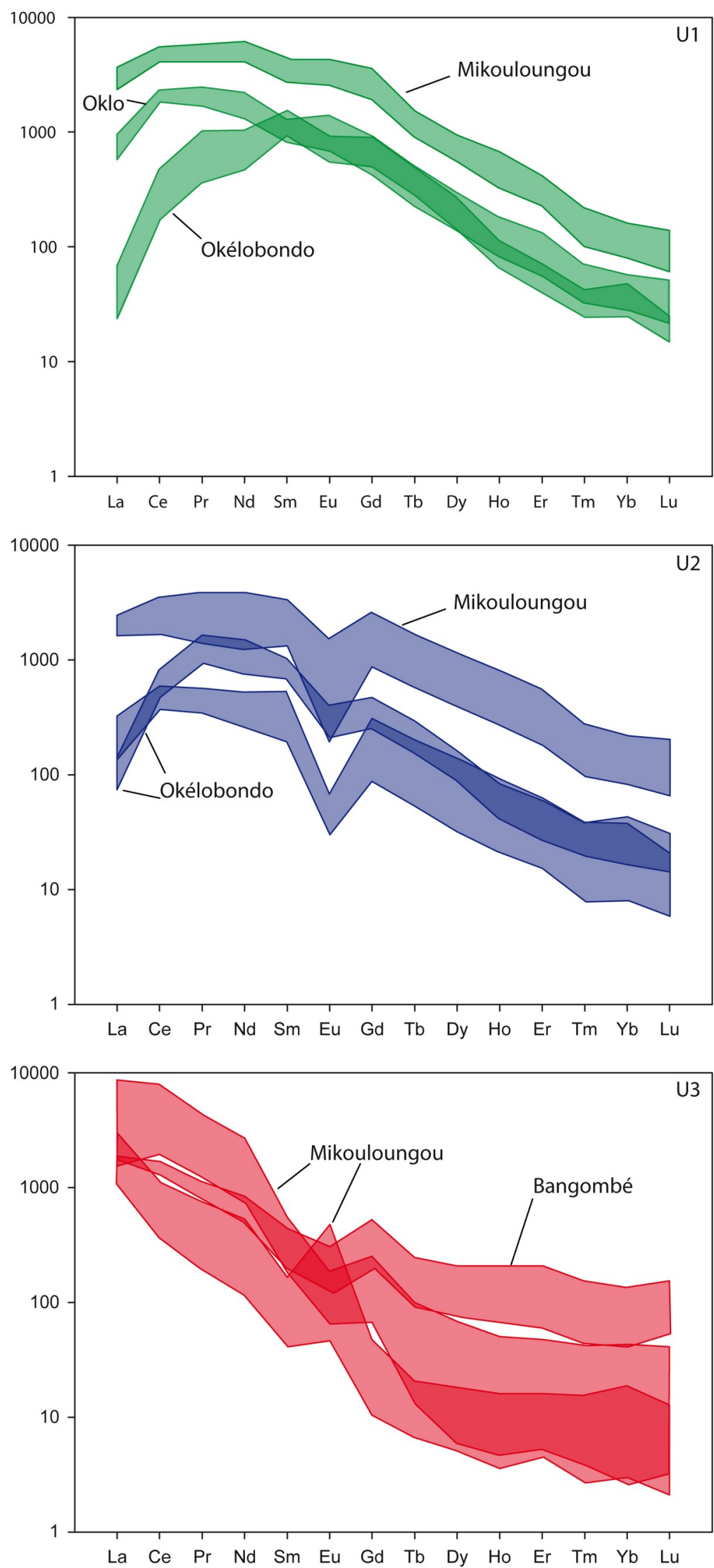

Fig. 10. REE patterns in U1, U2 and U3 uraninites from Mikouloungou, Bangombé and Oklo-Okélobondo locations. 

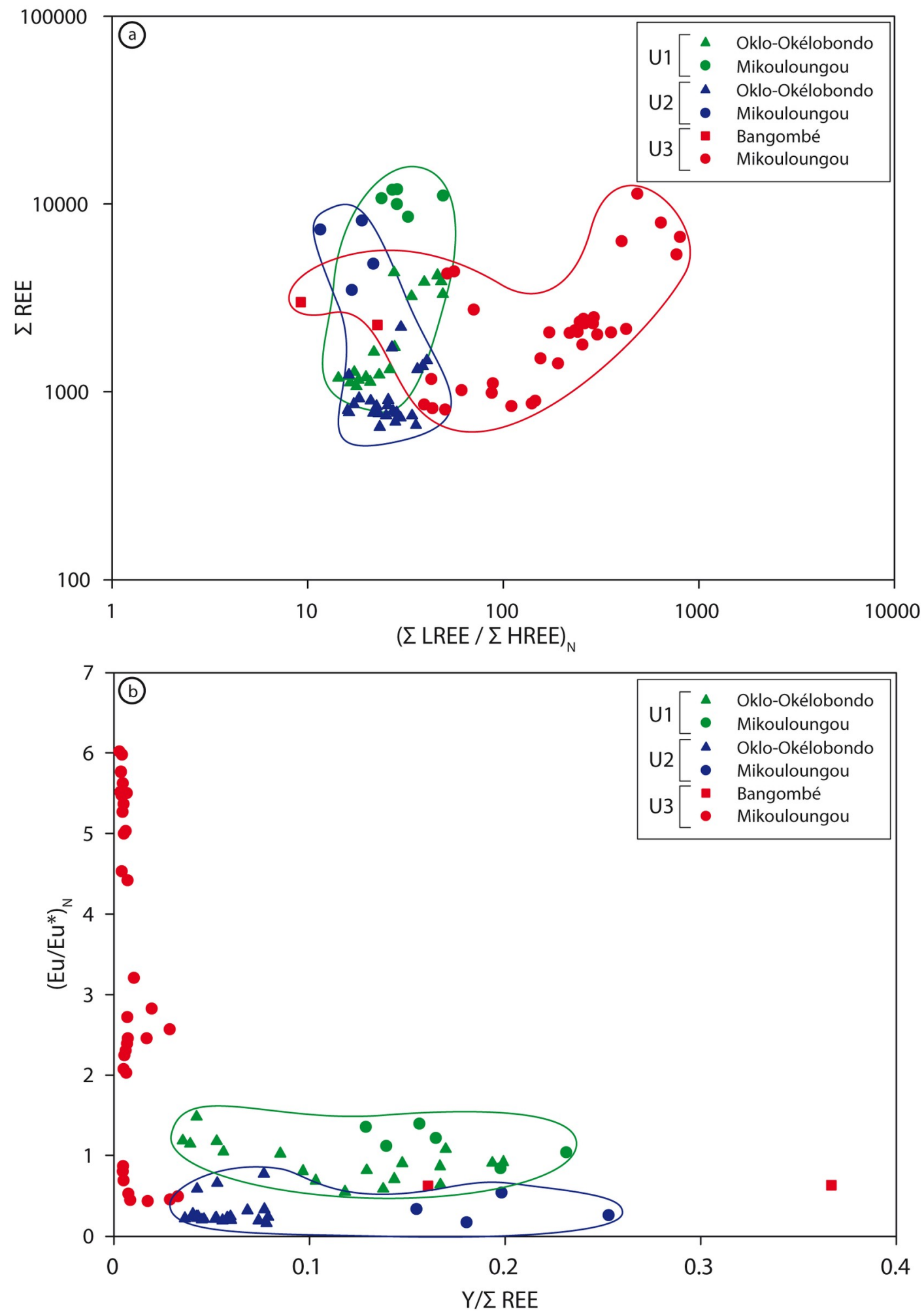

Fig. 11. $\Sigma$ REE vs $(\Sigma \text { LREE / } \Sigma \text { HREE })_{\mathrm{N}}$ and Eu/Eu* vs Y/ $\Sigma$ REE diagrams in U1, U2 and U3 uraninites from Mikouloungou, Bangombé and Oklo-Okélobondo locations. 

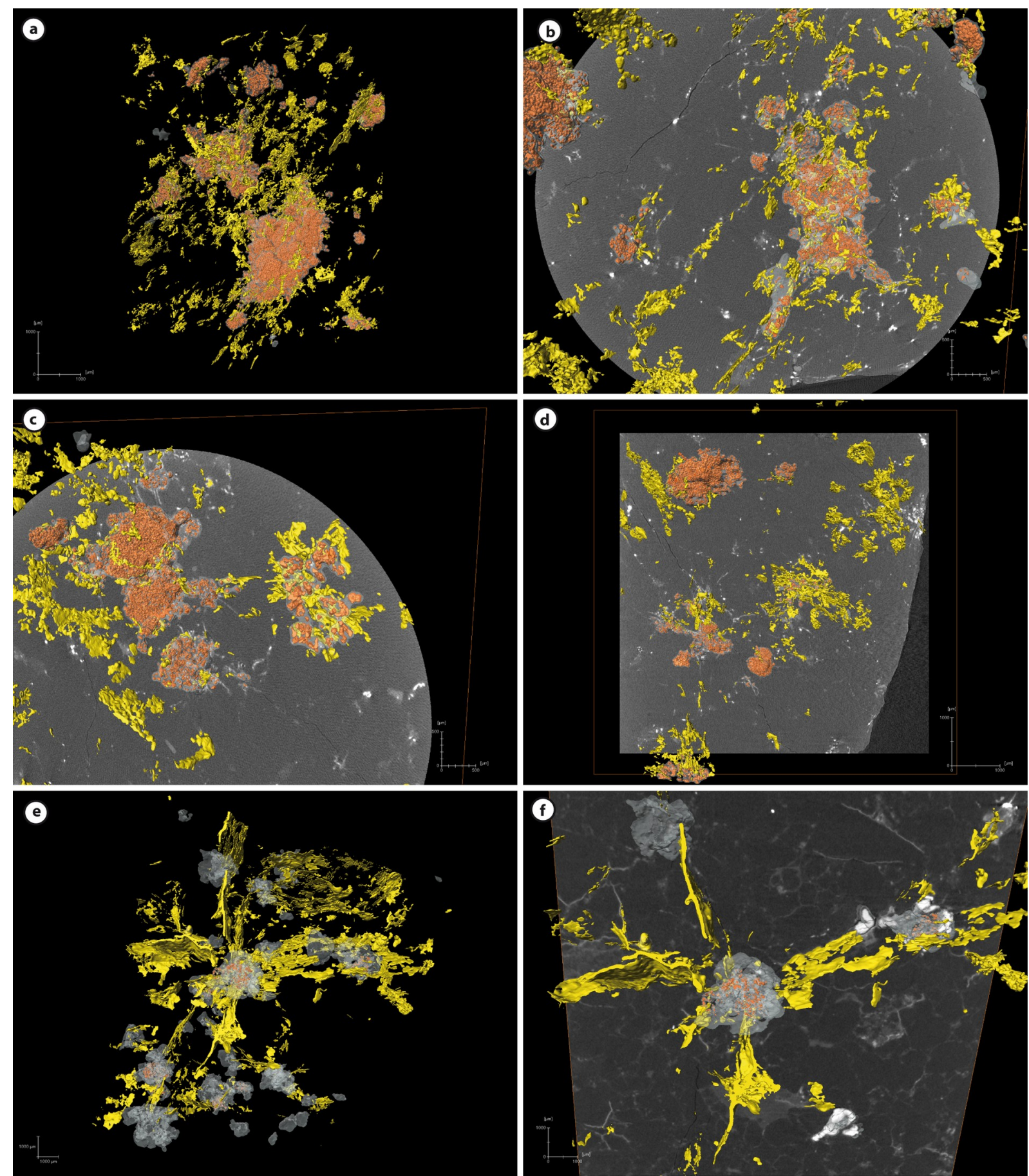

Fig. 12. 3D views from $X$-ray tomography on samples from Okélobondo (a to d) and Bangombé (e and f). U1-U2 are in orange, U3 in yellow and bitumen nodules are in transparent white. One video of 3D reconstruction can be downloaded from supplementary materials. 

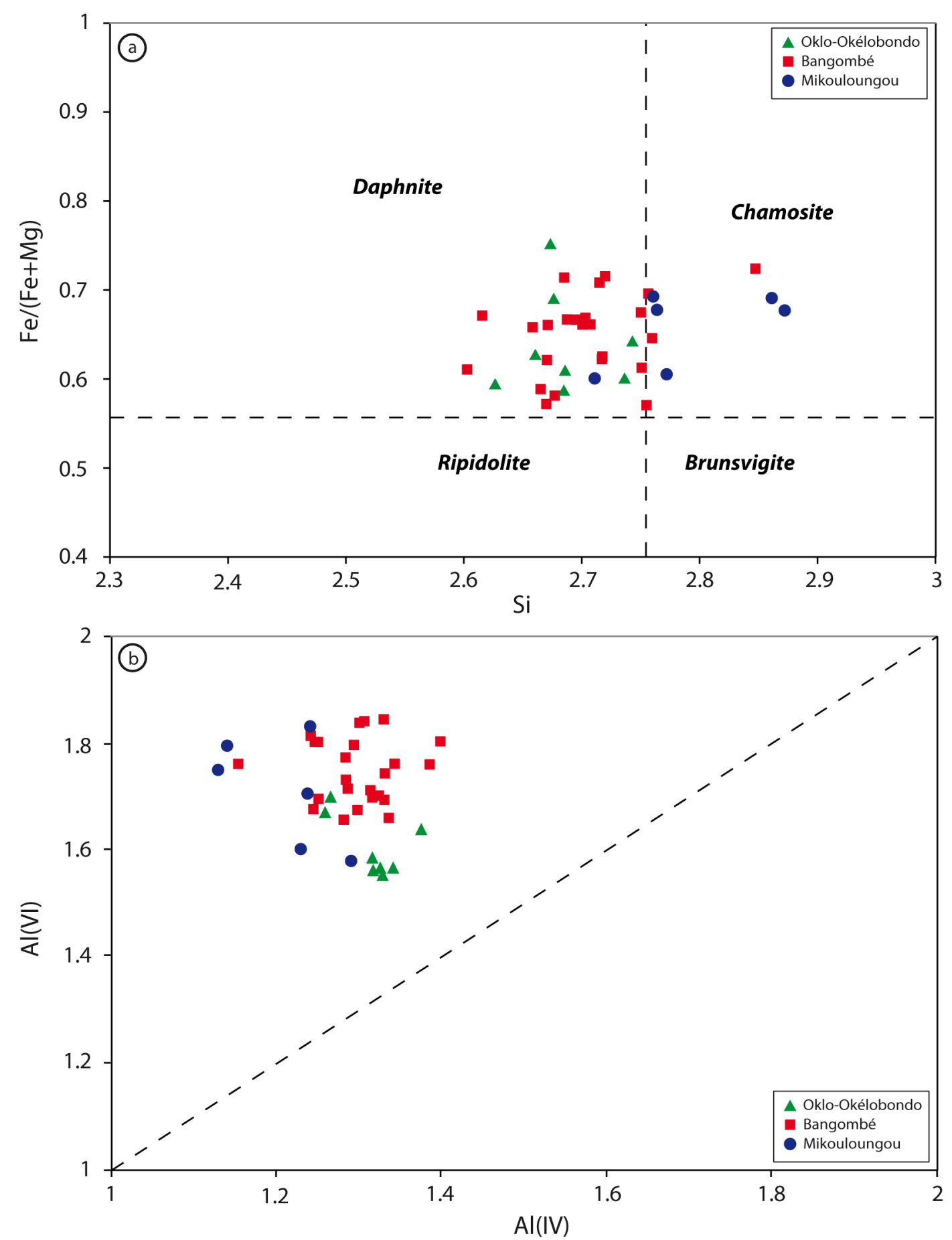

Fig. 13. $\mathrm{Fe} /(\mathrm{Fe}+\mathrm{Mg})$ vs $\mathrm{Si}$ and $\mathrm{Al}(\mathrm{VI})$ vs $\mathrm{Al}(\mathrm{IV})$ diagrams for Fe-chlorites in Oklo-Okélobondo (green triangles), Bangombé (red squares) and Mikouloungou (blue dots) samples. 


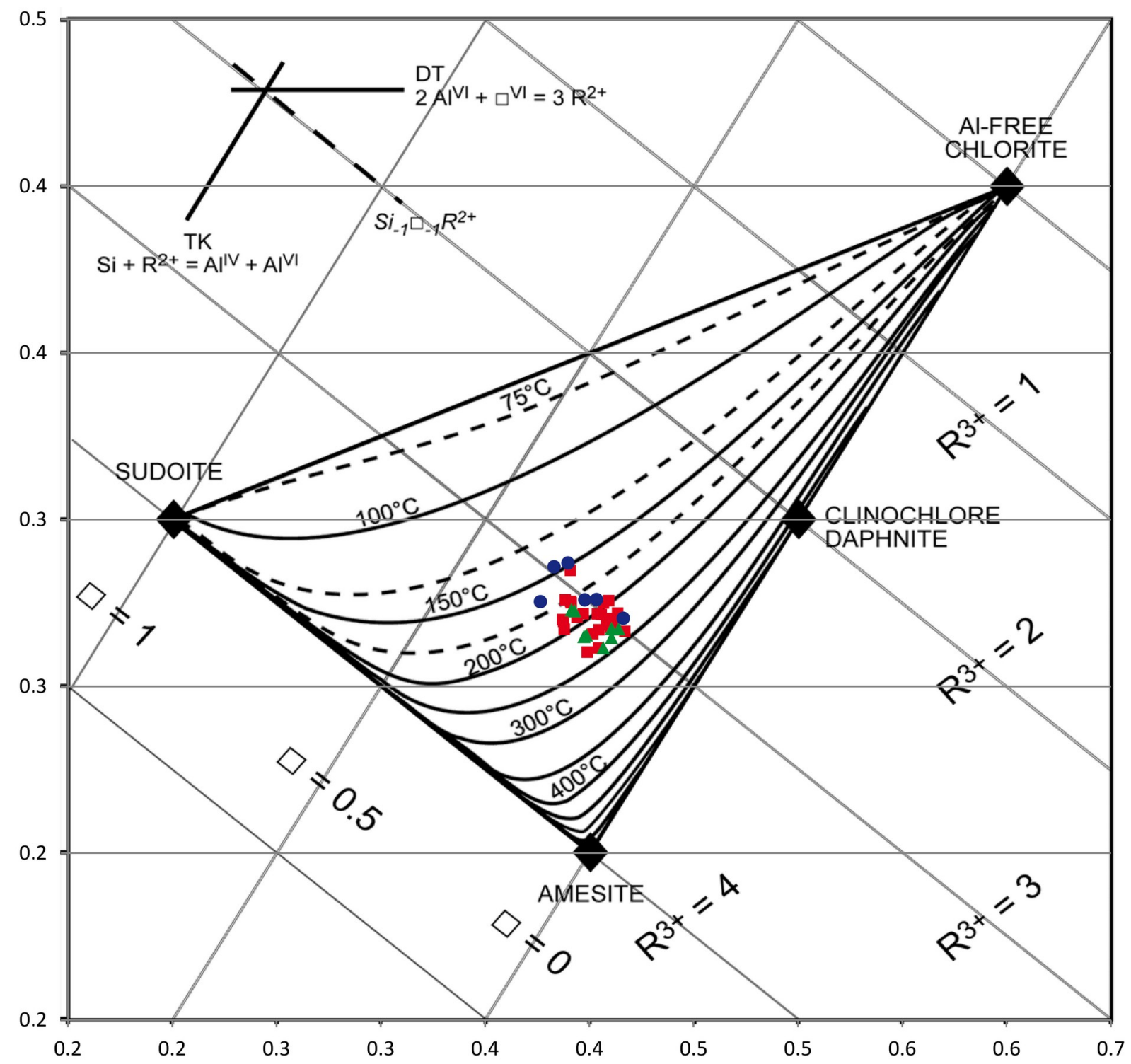

Fig. 14. Si vs $\mathrm{R}^{2+}$ diagram (Bourdelle \& Cathelineau, 2015) for Fe-chlorites in Oklo-Okélobondo (green triangles), Bangombé (red squares) and Mikouloungou (blue dots) samples. 


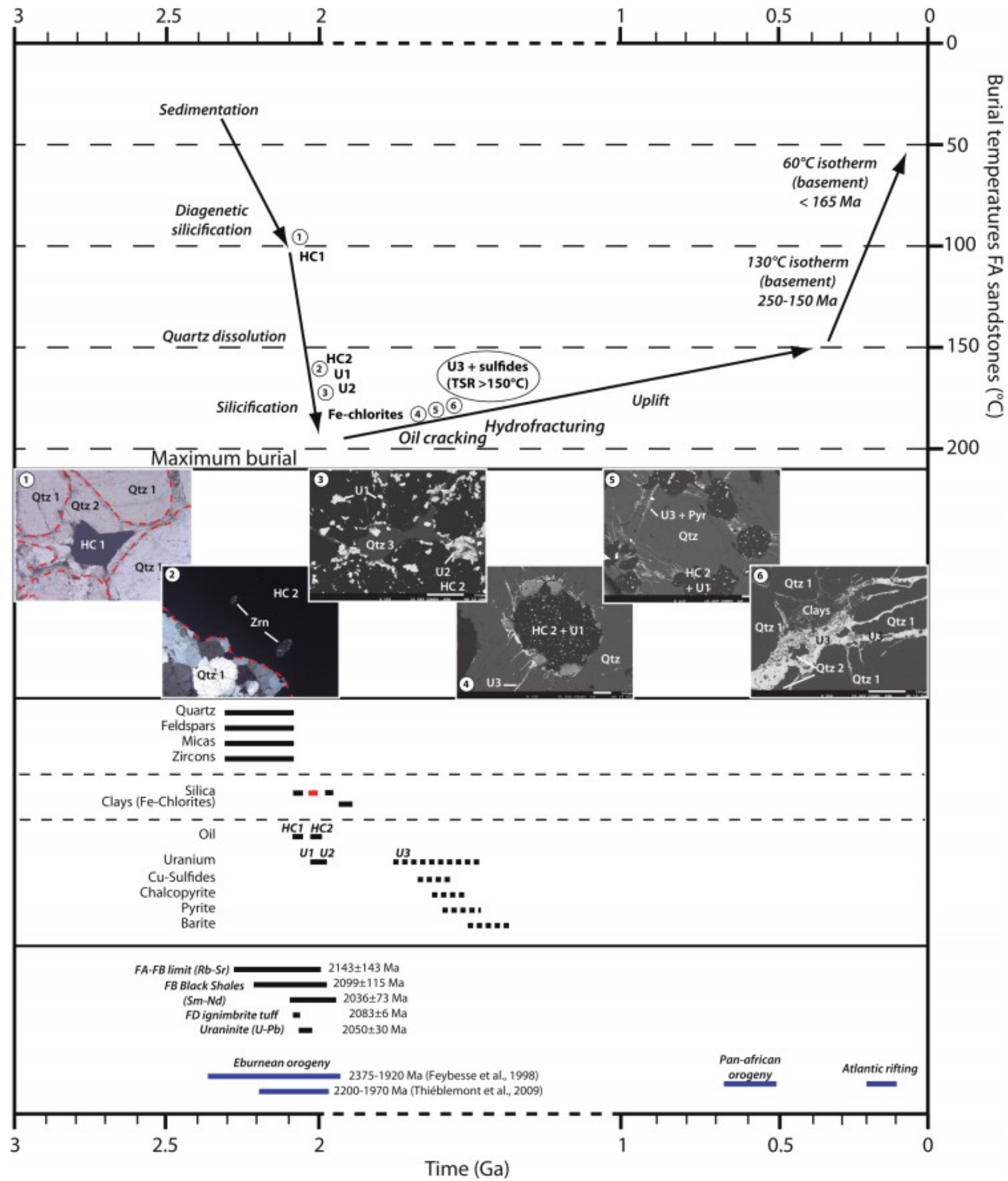

Fig. 15. Summary diagram of oil migration and uranium mineralization in FA sandstones. Additional age data are summarized in Gauthier-Lafaye (2006). Orogeny ages are from Feybesse et al., 1998 and Thiéblemont et al., 2009.A complete list of previous data can be found in Mathieu (1999). 